\title{
The Determinants of Election to the United Nations Security Council
}

\author{
Axel Dreher \\ Heidelberg University \\ Matthew D. Rablen \\ Brunel University
}

\author{
Matthew Gould \\ University of Westminster \\ James Raymond Vreeland \\ Georgetown University
}

June 2013

\begin{abstract}
The United Nations Security Council (UNSC) is the foremost international body responsible for the maintenance of international peace and security. Members vote on issues of global importance and consequently receive perks - election to the UNSC predicts, for instance, World Bank and IMF loans. But who gets elected to the UNSC? Addressing this question empirically is not straightforward as it requires a model that allows for discrete choices at the regional and international levels; the former nominates candidates while the latter ratifies them. Using an original multiple discrete choice model to analyze a dataset of 180 elections from 1970 to 2005, we find that UNSC election appears to derive from a compromise between the demands of populous countries to win election more frequently and a norm of giving each country its turn. We do find evidence that richer countries from the developing world win election more often, while involvement in warfare lowers election probability. By contrast, development aid does not predict election.
\end{abstract}

Keywords: United Nations, Security Council, turn-taking norm, elections

JEL: F53, F55, O19

Acknowledgements: For comments, we thank three anonymous reviewers and the editors of this journal, Eunbin Chung, Simon Hug, Diego Dewar, participants of the Political Economy of International Organizations VI conference at the Universities of Mannheim and Heidelberg; and seminar participants at the Georgetown University International Theory and Research Seminar (GUITARS). 


\section{Introduction}

Endowed with the legal power to authorize whatever foreign policies it deems necessary to maintain international peace and security, the Security Council has become the preeminent organ of the United Nations (UN). It has the legal authority to suspend economic and diplomatic relations between countries, impose blockades, and authorize the use of armed force (see Voeten 2001; Hurd 2007; Chapman 2011). The body includes 15 members: the five ever-present Permanent Members, and the ten Non-Permanent Members (NPMs), who must win election to serve limited two-year terms.

Our study seeks to explain which countries win election to the United Nations Security Council (UNSC) as NPMs. Note that at least four NPMs must vote in favor of a resolution for it to pass, giving these members a central role on the world stage. The President of the Security Council - a position that rotates among the members - has influence over the agenda and the order of voting (Bailey and Daws 1998: 130-131). Most importantly, the UNSC votes by open ballot so that the voice of an elected member has a global reach on central matters of world security. Accordingly, some countries appear willing to bribe and reward NPMs. For instance, the United States increases bilateral foreign aid by more than $50 \%$ when a country serves on the UNSC (Kuziemko and Werker 2006). Also, NPMs become more likely to receive World Bank project loans and International Monetary Fund (IMF) loans with relatively soft conditionality (Dreher et al. 2009a; 2009b; 2010). Asian NPMs see their loans from the Asian Development Bank rise around 30\% (Lim and Vreeland 2013).

Understanding which countries receive these rewards can serve to inform longstanding economic questions over the allocation and effects of foreign aid and IMF/World Bank loans (see, e.g., Rajan and Subramanian 2008; Bueno de Mesquita and Smith 2010). Does the UNSC election process direct these funds towards countries with particular characteristics? Kuziemko and Werker (2006: 909), following Malone (2000), assert that "Service on the 
Council is by no means random." Yet, to our knowledge, no established study details the systematic determinants of election to the Security Council. ${ }^{1}$

The power to elect the NPMs formally rests in the hands of the United Nations General Assembly (UNGA), which includes delegates from all UN member countries. Usually, however, the UNGA vote serves as a mere ratification of decisions made by regional caucuses, which play a privileged role in the nomination process. Only when there remains disagreement at the regional level, which happens in about $20 \%$ of elections, does the UNGA vote become meaningful. On these occasions, the interplay of two separate sets of preferences - those at the regional level and those at the global level (the UNGA) - determine election to the UNSC.

What shapes these preferences? To choose NPMs, the UN Charter calls on government representatives to consider "the contribution of members of the United Nations to the maintenance of international peace and security and to the other purposes of the Organization.” In practice, however, matters are more complex. A detailed set of procedural rules and at least two unwritten gentlemen's agreements also shape the UNSC election procedure. Moreover, UN Ambassadors appear to consider factors beyond contributions to peacekeeping: political affiliations, economic strength, and foreign aid may all play a role. For instance, Iceland's sudden financial collapse in 2008 seemingly derailed what had

\footnotetext{
${ }^{1}$ Bueno de Mesquita and Smith (2010) briefly analyze the determinants of UNSC membership with a probit model, but the authors focus on the effects of membership. Region-specific studies have been published. Lim and Vreeland (2013) use a logit model conditioned on year to examine the election of Asian countries. Scharioth (2010) analyzes the election of Western European countries to various UN committees. Part of the work here is based on our earlier working paper (Dreher and Vreeland 2009). Two other working papers on the election of UNSC members that have been presented at conferences include Iwanami (2012) and Schmitz and Schwarze (2012). Thorough qualitative accounts of the selection of specific UNSC members have been published, e.g., Malone (1998; 2000), and Jayakumar (2011).
} 
previously looked a secure candidacy, while US support for the candidature of Guatemala appeared important in stymieing the rival candidacy of Venezuela in 2006. Cases such as these might just represent idiosyncrasies, but they may also be part of a regular pattern. How then should one go about investigating the systematic determinants of UNSC election?

To investigate discrete choice settings, scholars often employ the conditional (fixed effects) logit model in which a single decision-maker chooses a single option according to utility maximization (see McFadden 1973). The UNSC election process differs from this model in at least two respects. First, as discussed above, up to two different sets of preferences can be in play: the regional and the global. Second, in some election years the UNGA regularly elects two candidates from one region, not just a single candidate. We therefore develop a multiplediscrete choice model that extends the conditional logit model to allow, in a simple way, for the separate identification of two intermingling sets of preferences, and for the number of choices from the set of alternatives to vary (from zero to two).

Our empirical analysis of election to the UNSC considers five broad theoretical questions: $(i)$ Does the UNGA follow a norm of choosing countries committed to peace, as directed by the UN Charter? (ii) Does the receipt of foreign aid predict UNSC election? (iii) Is election driven by international power or close relationships with powerful countries? (iv) Do cultural traits play a role? $(v)$ Do governments practice a turn-taking norm of sharing seats by rotating through the eligible candidates? The last question derives from the common misconception that membership on the UNSC "rotates" through the full UN membership roster. Formally, membership does not rotate, but in practice the regional groups and the UNGA might follow such a norm.

Analyzing data on UNSC elections between 1970 and 2005, we find some evidence of a commitment to peace. At least countries engaged in intra- or inter-state conflict since the end of the Cold War are less likely to win election from Africa or from Latin America and the 
Caribbean. There is also a positive link between troop contributions to UN peacekeeping missions and election from Africa and Asia.

As for international power, all regions except Eastern Europe exhibit some evidence of a preference for populous countries. We also find evidence that richer countries, measured by gross national income (GNI) per capita, enjoy an advantage in Africa, Asia, and Latin America.

We find only patchy, and somewhat mixed, evidence that foreign financial support determines election. US development assistance does not predict election from the developing world, and US military support similarly plays little role in regional decisions. When the UNGA votes, however, countries that receive US military assistance - as opposed to development aid - are more likely to win election. ${ }^{2}$

Political-cultural factors appear to hold occasional influence within regions. Governments that share a common political ideology with their region are more likely to be elected from Eastern Europe and Latin America, but not from other regions. Colonial legacy also has mixed effects. A British colonial legacy helps in Asia, Latin America, and Western Europe but not in Africa. Corruption also has inconsistent effects. It pays off only in Africa and Latin America, and the effect in Africa is of marginal statistical significance. In contrast to these findings, the UNGA as a body has shunned corrupt countries since the end of the Cold War. Indeed, our results suggest the presence of significant heterogeneity in the determinants of UNSC election across regions. Therefore, while culture and history have marginal and inconsistent effects within regions, they may drive substantial differences across regions.

\footnotetext{
${ }^{2}$ Strictly speaking, US military aid does not count as official overseas development assistance, according to the Organization of Economic Co-operation and Development (OECD).
} 
"Turn-taking" stands as the only finding that holds across all regions and time periods without exception. A country whose turn arrives is more likely to receive regional nomination, which accords with the common "rotation" perception. These regional turntaking rights do not, however, hold sway in elections contested at the UNGA level.

The results of this study contribute to the ongoing discussion of UNSC reform, which centers on the question of representation but lacks a systematic study of membership (see Hosli et al. 2011). Our analysis also connects to the literature on leader selection (e.g., Hamermesh and Schmidt 2003, Besley and Reynal-Querol 2011). Importantly, we further contribute a generic econometric model of elections wherein there is a nomination process at one level and an endorsement vote at another (also see Glasgow et al. 2012 and Golder et al. 2012).

The paper proceeds as follows. Section 2 outlines the UNSC election process, and Section 3 presents various hypotheses about the determinants of election. In Section 4 we formally develop the econometric model, providing a likelihood equation for UNSC election, and discuss important methodological details. Section 5 presents the results, and Section 6 concludes with some implications of our main findings.

\section{The election process}

The UNSC election process for NPMs follows certain rules and agreements. ${ }^{3}$ The ten NPM seats are divided among five regional caucusing groups: one country from Eastern Europe (EE); two from the Western European and Others Group (WEOG); two from the Latin America and Caribbean Group (GRULAC - el Grupo Latinoamericano y Caribeño); and five

\footnotetext{
${ }^{3}$ Some background for this section comes from Security Council Report, an independent not-for-profit organization: http://www.securitycouncilreport.org. We also draw on Luck (2006).
} 
from Africa and Asia. ${ }^{4}$ An unwritten, but unbroken, gentlemen's agreement divides the five seats for Africa and Asia into three seats for Africa and two seats for Asia. Around 1968, a further unrecorded agreement between Africa and Asia reserved one of their five seats for an Arab state, with the regions taking turns every two years to provide a suitable candidate (Security Council Report 2011: 7). This seat is often called the "Arab swing seat."

The UNGA conducts staggered elections for five seats every autumn. Terms begin the following January. ${ }^{5}$ To be eligible for election, a country must, first, belong to one of the five regional caucusing groups. Prior to 2000, when it gained temporary membership in the WEOG, Israel was not a member of any group (Security Council Report 2011: 6); and Estonia, having joined the UN in 1991, did not become a member of the Eastern European (EE) caucus until 2004 (Estonia 2011) while it awaited the outcome of an (ultimately unsuccessful) application to the WEOG (Daws 1999). The small island-country of Kiribati, which has never designated a permanent representative to the UN, is the only country to presently have no group affiliation (UN 2012). Second, NPMs in the final year of their terms cannot run for immediate re-election (UN Charter 23(2)).

\footnotetext{
${ }^{4}$ The "others" in the modern-day WEOG include descendent countries of Western Europe, mainly from the British Commonwealth: Australia, Canada, and New Zealand. The United States also caucuses with this group, as do Turkey and, more recently, Israel (see, e.g., Security Council Report 2011). Before 1966, there were only six elected UNSC members. See Daws (1999) for the development of the UN regional groups.

${ }^{5}$ The Eastern European term begins in even years. The two WEOG terms begin in odd years. The GRULAC and ASIA stagger their two terms; the UNGA elects one from each of these groups every year. Africa's three terms are also staggered: two begin in even years and one in odd years. The Arab term (shared between Asia and Africa) begins in even years.
} 
Countries may declare candidacy by notifying the chairman of their regional group. ${ }^{6}$ Before voting begins in the UNGA, the chairman of each group announces the countries that have declared candidacy (the chairman's list). ${ }^{7}$ Although details of the regional negotiations are scarce, there appears to be a preference for the choice of NPMs to be kept "in house," insofar as is possible. The vote in the UNGA is, as a result, usually sidelined by regional groups offering a "clean slate," whereby the chairman announces only as many candidatures as seats available. Contested elections, when the chairman announces more candidatures than seats available, appear to occur when efforts at agreement at the regional level have failed. ${ }^{8}$

Africa appears to have the most disciplined rules for selecting candidates. ${ }^{9}$ It operates a system of turn-taking within sub-regional groups, which should, in theory, ensure that all countries in Africa eventually serve on the Security Council. ${ }^{10}$ Even here, however, the situation is more complex than might first appear. According to the independent not-for-

\footnotetext{
${ }^{6}$ We know from the UNGA's minutes that group chairmen stand up in sequence before the vote and announce the group's candidates. The chairman position rotates among the region members, and terms last one month. See various issues of the Journal of the United Nations for details on specific elections (http://www.un.org/en/documents/journal.asp, accessed 5 April 2012).

${ }^{7}$ Sometimes countries announce their intention to run years in advance. Other times they do so much later, even in the midst of elections. The timing of such announcements appears idiosyncratic, and data are not available.

${ }^{8}$ For the 36 election-years (1970-2005) we analyze, the WEOG is the most competitive group, with nine contested elections, and EE is the least competitive, with just five. As we detail further in footnote 23, we define an election as "contested" if an additional candidate receives ten votes or more. Using this threshold, there are a total of 36 "contested" elections out of 180 total elections, or $20 \%$.

${ }^{9}$ Africa is the only region for which we have found explicit rules, codified by the African Union in their "Rules of Procedure of the Ministerial Committee on Candidatures within the International System - Doc. EX.CL/213 (VIII).” See African Union (2006: 8).

${ }^{10}$ North Africa and Central Africa rotate one seat every two years; Western Africa has one seat every two years; and Eastern Africa and Southern Africa rotate one seat every two years. See Security Council Report (2011: 6).
} 
profit organization known as Security Council Report (2011: 6) there are at least three complications. First, some countries that straddle more than one sub-region have shifted from one to another. Second, challengers can emerge within the same sub-regional grouping, upsetting the rotation. ${ }^{11}$ Last, within a subgroup, some members may choose to run more often, while others choose, or are persuaded, to run less frequently or not at all.

To win election, a country must receive at least two-thirds of the votes in the UNGA (UN Charter 18(2)). In theory, members of the UNGA face no requirement to vote for “chairman's list" countries, though in practice they seldom do otherwise (save for isolated protest votes). Therefore, to date, after a chairman has announced a "clean slate" the UNGA has almost always ratified the regional selection. When there are multiple candidates, if no candidate meets the two-thirds threshold for a specific regional seat, the UNGA holds runoff elections, allowing any country from the region to enter the subsequent elections (and allowing write-in candidates on ballots). Runoff elections for remaining seats continue until all seats have been filled by countries winning two-thirds of the UNGA votes. On rare occasions, no country has garnered the required two-thirds majority after many rounds. In these cases, the leading candidates have withdrawn, ceding the election to a compromise candidate.

\section{Hypotheses}

Who wins election to the UNSC? Bueno de Mesquita and Smith (2010) present a cursory examination of this question using a simple probit model in an effort to show the exogenous

\footnotetext{
${ }^{11}$ According to the Security Council Report (2009: 6), such queue-jumping occurred three times in the sample period: Ghana queue-jumped Liberia in 1985, and Nigeria queue-jumped Niger in 1977 and Guinea-Bissau in 1993. In the last case, Rwanda and Guinea-Bissau had been nominated for the two African seats. Rwanda garnered sufficient votes (153) in the first round to win election, while Guinea-Bissau received only 82 votes, at which point Nigeria entered the race, winning in four rounds.
} 
nature of UNSC membership selection for their study of the effects of membership. ${ }^{12}$ No published study has presented, however, a tightly focused examination of the question of UNSC election using quantitative methods. In the next section, we offer the main contribution of our paper: a multiple-discrete choice model to examine the joint determinants of UNSC election at the regional and global levels. First, however, we draw on the broad literature in international relations and political economy, as well as qualitative accounts of UNSC election, to develop the testable hypotheses that we apply to our statistical model.

We begin with the UN Charter, which asks members of the UNGA to elect UNSC members on the basis of their contributions to the maintenance of international peace and security. We thus test the impact of the contributions that countries make to UN peacekeeping missions, measured as the log of the number of troops supplied. We also include an indicator variable for countries involved in intra- and/or inter-state conflict. We further test for an effect of democracy, which is often associated with openness, justice, and peace. ${ }^{13}$

Two further hypotheses reflect the political economy literature. A growing body of work shows that countries receive perks from UNSC membership, including US foreign aid (e.g., Kuziemko and Werker 2006), World Bank projects (Dreher et al. 2009a), and IMF programs with comparatively soft conditionality (Dreher et al. 2009b, 2010). If these same perks that result from UNSC membership were also found to predict UNSC membership, this would point to the presence of development cycles whereby countries that gain election receive perks that, in turn, increase their prospects of future election. To test this possibility, we

\footnotetext{
${ }^{12}$ Bashir and Lim (2013) challenge this assumption.

${ }^{13}$ On the association of democracy with openness, see Hollyer et al. (2011). On the association with justice see Dowding et al. (2004). On the general proclivity of democracies to peace, see Russett and Oneal (2001). For a contrasting view, see Ferejohn and Rosenbluth (2008).
} 
consider whether US economic and military assistance, IMF program participation, and the number of new in-country World Bank projects, predict election to the UNSC. ${ }^{14}$

If countries expect perks from membership on the UNSC, then perhaps more heavily indebted governments push harder to be elected. Or causality may run the other way: perhaps when governments anticipate that they will be elected to the UNSC, they allow their countries to go deeper into debt, anticipating a bail-out on the horizon. Either way, levels of indebtedness may predict UNSC membership. We test this hypothesis using debt service as a percentage of gross national income.

If UNSC membership is valuable, heavily indebted countries may well desire membership, but they may not be in a strong position to win. Stiff competition for UNSC seats may lead the most powerful countries to win election most often. Having worked with the Canadian government in their successful 1998 election bid, Malone (2000) notes the importance of campaign funds. Canada, for example, apparently spent \$1.3 million. Scharioth (2010) argues that "realist" variables measuring a country's power predict election to a wide range of UN committees, at least for the WEOG. To test the impact of a country's strength, we consider

\footnotetext{
${ }^{14}$ IMF programs themselves come in cycles (Conway 2007). Omitting participation in IMF programs might thus bias our results in favor of finding a turn-taking norm. A substantial literature argues that IMF and World Bank loans might be given for political-economic reasons rather than need (e.g., Kilby 2009, 2013; Reynaud and Vauday 2009; Stone 2002). As for bilateral foreign aid, we limit our attention to the US role for two reasons: (1) its prominent place - both in quantitative magnitude and in the literature and (2) parsimony. If we include foreign aid from all potential countries, degrees of freedom become low in certain regions. Preliminary analyses of foreign aid patterns from other OECD countries did not reveal any statistically significant correlation with UNSC election. We suggest that more in-depth analyses - for example Japan's use of foreign aid to win favor be explored in country- or region-specific studies.
} 
three measures: population size (logged), per capita income (logged, measured in constant US\$), and territorial size (logged). ${ }^{15}$

A government's connections to powerful countries might also affect its election prospects. We measure international connections in four ways. First, we include two variables to capture how frequently each country votes in the UNGA with the United States and USSR/Russia, respectively. Second, we include an indicator for countries with "pariah" status in the eyes of one or more of the major powers, and hence subject to US and/or UN sanctions, as defined by Morgan et al. (2006). Third, we test whether the membership of various political groupings that operate within the UN - the Group of 77 (G77), Non-Aligned Movement (NAM), Organisation of Islamic Cooperation (OIC), and JUSCANZ (a subset of the WEOG including Japan, the United States, Canada, Australia, and New Zealand) - predicts UNSC election. ${ }^{16}$ Last, membership in other non-UN groupings may also be important, so we allow for an effect of membership in the European Union (EU) and NATO.

Cultural affinity may also matter. The variables we use to test the influence of culture include the percentage of the country that is Muslim or, alternatively, Catholic. We also test if a history of British or French colonization plays a role. ${ }^{17}$ Beyond religious and historical

\footnotetext{
${ }^{15}$ We use GNI/capita, as opposed to the more common GDP/capita, as it is the income measure used by the UN in the computation of member state contributions to the General and Peacekeeping budgets. We also follow the UN's methodology in using US\$ exchange rate estimates of GNI. International, rather than domestic, purchasing power is more relevant in this context.

${ }^{16}$ Because of substantial overlap in membership between G77 and NAM, indicator variables for membership in each cannot be included in the same regression equation. Instead we create three separate indicator variables: one for countries that are members of both groupings, and one for countries that are members only of NAM or only of G77, respectively.

17 Since it impacts foreign aid, UNSC membership may be a channel by which colonial history affects development. See Iyer (2010) and Bruhn and Gallego (2012).
} 
affinities, we test the importance of political affinity within the region, measuring the percentage of the region with which the chief executive shares the same broad political ideology (either left, center, or right). ${ }^{18} \mathrm{We}$ also consider another variable that may be related to culture: the level of corruption associated with a country. On the one hand, perceived corruption may hurt if regions and the UNGA disdain such countries. On the other, corruption may help if such countries willingly disregard norms of turn-taking, jumping the queue while paying whatever bribes necessary to win support.

Finally, behavioral norms that have evolved within the decision-making process may also play a role. One such norm, which is observed in human evolution as well as in a wide range of other species, is turn-taking (Colman and Browning 2009; Franz et al. 2011). In the context of the UNSC election process, the turn-taking norm implies that membership on the UNSC should rotate among the members of each caucusing group. This turn-taking norm relates to the egalitarian norm, which features importantly in the literature on distributive justice (e.g., Rawls 1971) and is consistent with recent models of inequity-aversion (e.g., Fehr and Schmidt 1999).

The Africa group explicitly claims to operate according to the turn-taking norm, but whether some degree of turn-taking actually occurs among the remaining regions is less clear. To test the possibility that a region practices the turn-taking norm, we construct a variable, "turntaking," which is calculated as the number of years a country has waited to serve on the

\footnotetext{
${ }^{18} \mathrm{We}$ calculate the percentage of the region according to the number of the countries in the region - minus the country in question - sharing the same ideology (left, center, or right). The variable is coded zero for nonideological governments. See Beck et al. (1999) for the coding of ideology.
} 
UNSC divided by the number of countries currently eligible for election. ${ }^{19}$ If the turn-taking norm holds, this variable should be positively correlated with election.

Thus, we consider five broad perspectives: (i) a commitment to peace, (ii) a foreign aid story, (iii) a realist international relations perspective, (iv) a cultural approach, and (v) a turn-taking norm. Table 1 summarizes our hypotheses and the variables we use to test them along with their sources.

\section{Econometric Model and Methodology}

\subsection{Preliminaries}

Let the set of members of the UNGA in year $t$ be decomposed into the set of member countries with permanent member status $(P M)$ and the set of all other "ordinary" member countries. Denote $J=\{$ Africa,Asia,EE,GRULAC,WEOG $\}$ as the set of caucusing groups (regions), and let the set of ordinary member countries belonging to region $j$ in year $t$ be denoted $R_{j t}$, where $t \in\{0, \ldots, T\}$. We let $R_{j}=\cup_{t} R_{j t}$ denote the set of all past and present members of caucusing group $j$, and we define $C_{i j}$ as the $i^{\text {th }}$ country within $R_{j}{ }^{20}$ The set of ordinary member countries belonging to a caucusing group in year $t$ (a necessary condition to

\footnotetext{
${ }^{19}$ Using the model, which we present in the next section, we tested several possible measures of a turn-taking norm against a benchmark of perfect turn-taking. In a given year, let $t_{i}$ denote the number of years since country $C_{i j}$ was last elected to the UNSC (or since it entered the UN, if no such instance), $\bar{t}$ denote the mean of $t_{i}$, and $\eta$ denote the number of countries, excluding $C_{i j}$, eligible for election. The measures we considered were: (1) $t_{i}$; (2) $t_{i} / \eta$; (3) $t_{i}-\eta$; (4) $\mathbf{1}_{\left\{t_{i}>\bar{t}\right\}}$; and (5) $\left(t_{i}-\bar{t}\right) \mathbf{1}_{\left\{t_{i}>\bar{t}\right\}}$, where $\mathbf{1}_{\{A\}}$ is the function taking the value 1 if condition $A$ is true and 0 otherwise. We found the second of these measures to be best suited for capturing turn-taking effects.

${ }^{20}$ Our analysis accounts for the creation of new nations and the disappearance of existing ones. These events change the sample size, which complicates the calculation of the marginal effects. We discuss this issue in depth below.
} 
serve as a NPM in year $t+1)$ is therefore $R_{t}=\cup_{j} R_{j t}$.

Let $N P M_{t}$ denote the set of NPMs on the UNSC in year $t$, then the UNSC in a given year, $t$, is defined by $U N S C_{t}=N P M_{t} \cup P M$. In any given year a set of ordinary member countries NPMs in the first year of their terms - gain automatic membership on the UNSC in the following year: $A_{t}=N P M_{t} \backslash N P M_{t-1}$. A second set of ordinary member countries, those that are in the final year of their terms on the UNSC, are ineligible for election to the UNSC in the following year: $I_{t}=N P M_{t} \cap N P M_{t-1}$. The remaining ordinary member countries are eligible for election to the UNSC in the following year: $E_{t}=R_{t} \backslash N P M_{t}$. Last, historical data on nonpermanent membership of the UNSC are summarized by the indicator variable $d_{i j t}$, where $d_{i j t}$ $=1$ for $C_{i j} \in N P M_{t}{ }^{21}$

\subsection{Preferences}

Denote the utility to the members of region $j$ from electing country $C_{i j}$ in period $t$ to the UNSC (to serve in periods $t+1$ and $t+2$ ) as $u_{i j t}=\boldsymbol{\beta}_{j} \mathbf{x}_{i j t}$, where $\mathbf{x}_{i j t}$ contains the characteristics of $C_{i j}$ in year $t$ and $\boldsymbol{\beta}_{j}$ contains the preference weights of region $j$. Similarly, denote by $u_{i j t}^{G A}=$ $\boldsymbol{\beta}^{G A} \mathbf{x}_{i j t}$ the utility to the members of the UNGA of electing country $C_{i j}$ in period $t$.

Election to the UNSC can be conceived of as a two-stage process. In the first stage, the regional groups make nominations, resulting in the chairman of each region announcing to the UNGA a set of candidate countries $N_{j t} \subseteq E_{j t}$ for election to the UNSC. In the second stage, the UNGA votes. As discussed in Section 2, because members of the UNGA almost always choose to vote for members of $N_{t}$, the vote in the second-stage can be viewed as taking place over these countries only.

One approach to estimation is to model this two-stage process explicitly (see, e.g., de Vries et

\footnotetext{
${ }^{21}$ UNSC membership data are found on its official website (http://www.un.org/Docs/sc).
} 
al. 2009). The resulting likelihood function is complex, however, and often fails to converge in estimations that include more than a few variables.

Instead, we simplify the problem in two important ways. First, we treat the decision-maker in the first stage (the region) as myopic. That is, the region's selection does not depend on how the UNGA will act. To allow for strategic interdependence would make our model intractable. Moreover, we suspect that regions do not act strategically in proposing candidates, although we acknowledge that individual countries have made strategic decisions to enter - or not to enter - specific elections.

Second, we treat the actors in each stage as unitary decision-makers. We make this simplification because we are interested in a country's overall chance of election onto the UNSC. Our reduced-form representation of the real election process should be a good approximation because the vast majority of elections result in landslides for the winning candidate. Regions tend to operate by consensus while the two-thirds majority rule in the UNGA tends to produce a single dominant candidate - with some exceptions. These exceptions notwithstanding, our decision to model each collective decision-maker as a unitary actor allows us to construct an estimable model that proxies the typical election process fairly well. Future work might explore modifications to one or more of these assumptions. ${ }^{22}$ One could, for instance, model the UNGA as a collective and estimate how many votes the candidate-countries receive.

Under these assumptions we may employ a simple mathematical formulation to capture the idea that election to the UNSC may be co-determined by two separate sets of preferences: those of the caucusing group (which shape the nominations) and those of the UNGA (which votes over nominated candidates). Specifically, we model UNSC election as arising from a

\footnotetext{
${ }^{22} \mathrm{We}$ are grateful to an anonymous reviewer for these two possible extensions.
} 
composite latent utility function, $U$, of electing $C_{i j}$ at time $t$, given by

$$
U_{i j t}=\alpha_{j t} u_{i j t}^{G A}+\left(1-\alpha_{j t}\right) u_{i j t}+\varepsilon_{i j t}
$$

which is a weighted average of the underlying regional and UNGA preferences, plus a stochastic component $\varepsilon_{i j t}$. The parameter $\alpha_{j t} \in[0,1]$ measures the weights attributable to the preferences of the UNGA, and may vary by region and year. In particular, we relate $\alpha_{j t}$ to the size of $N_{j t}$. If $\left|N_{j t}\right|$ equals the number of eligible seats, $n_{j t}$, the UNGA merely "rubber stamps" the clean slate of nominations from the caucusing group, and its preferences play no role $\left(\alpha_{j t}\right.$ $=0$ ). At the other end of the spectrum, if $\left|N_{j t}\right|=\left|E_{j t}\right|$ (every eligible member of a region is nominated to the UNGA), the regional preferences play no direct role, thus $\alpha_{j t}=1$. We assume that $\alpha_{j t}$ adjusts linearly between these two extremes: $\alpha_{j t}=\left(\left|N_{j t}\right|-n_{j t}\right)\left(\left|E_{j t}\right|-n_{j t}\right)^{-1} .^{23}$

\subsection{Election Probabilities}

We view the elections to the UNSC as choosing, for each region, $n_{j t} \in\{0,1,2\}$ countries from the set of eligible countries according to the utility function $U_{i j t}$, where $n_{j t}=\left|N P M_{j t}\right|-\left|A_{j t}\right|$. This setting extends the well-known choice model of McFadden (1973) in two important

\footnotetext{
${ }^{23}$ We compute $\alpha_{j t}$ using Costa Rica (2005), which contains full UNGA voting records for all UNSC elections prior to 2004. Voting records for 2004 onwards come from the relevant UNGA minutes. Costa Rica (2005) does not explicitly identify the "chairman's list" countries. In the overwhelming majority of elections, the patterns of voting in the UNGA clearly identify the "chairman's list" countries (who garner large numbers of votes) from countries that merely are recipients of votes cast in protest or error (who garner only one or two votes). In a small number of cases, the voting patterns identify the "chairman's list" countries less clearly, as a country garners an intermediate number of votes between five and 15. In these cases we identify the set of "chairman's list" countries as those that received ten or more votes. Our main results are, however, robust to lowering the threshold down to three votes (thereby counting more elections as contested). Obviously as we employ higher thresholds than ten, there are fewer and fewer elections counted as contested and eventually the model does not converge.
} 
respects. First, the set of alternatives is time varying. This occurs because $(i)$ countries move between the sets $\left(A_{j t}, E_{j t}, I_{j t}\right)$ from year-to-year as a result of the realizations of $d_{i j t}$; and (ii) entry and exit from $R_{t}$, principally as new members join the UN and others leave. ${ }^{24}$ Second, the number of members to be chosen from $E_{j t}$ is also time-variant, and need not be unity.

The tractability of McFadden's model is lost when, as in the UNSC, more than a single alternative is chosen simultaneously. To retain tractability, we therefore model election by the UNGA as a sequential process, in which countries are elected one-by-one. This methodology develops that of Manski and Sherman (1980), who use a multiple-discrete choice model to examine household car purchases. Whereas a family may buy two of the same car brand, however, a country cannot have dual membership on the UNSC in any year, so we must explicitly rule out this possibility. Formally, in each of $n_{j t}$ rounds, there is a new realization of $\varepsilon$ and a single country from $E_{j t}$ is elected according to utility maximization $\left(d_{i j t}=1 \Leftrightarrow U_{i j t}>\right.$ $\left.U_{k j t} \forall k \neq i\right)$. In the case when $n_{j t}=2$, if the same country is elected in both rounds, the result is annulled and the whole process repeated until two distinct countries are selected.

If we assume, following Manski and Sherman (1980), that the $\varepsilon_{i j t}$ in equation (1) are independent across regions and time and have identical type-1 extreme value distributions, we then have that: ${ }^{25}$

$$
\begin{gathered}
\operatorname{Pr}\left(d_{i j, t+1}=1 \mid C_{i j} \in A_{j t}\right)=1 ; \quad \operatorname{Pr}\left(d_{i j, t+1}=1 \mid C_{i j} \in I_{j t}\right)=0 ; \\
p_{i j t}^{0} \equiv \operatorname{Pr}\left(d_{i j, t+1}=1 \mid C_{i j} \in E_{j t}, n_{j t}=0\right)=0 ;
\end{gathered}
$$

\footnotetext{
${ }^{24}$ In the sample period 68 countries joined the UN, and four (Czechoslovakia, East Germany, Yemen Arab Republic, and Yugoslavia) left. Table 2 provides further details.

${ }^{25}$ Elections are not independent across time, however. Each year's election depends on the outcome of the previous year's election in a recursive manner, owing to the evolution of $E_{t}$.
} 


$$
\begin{gathered}
p_{i j t}^{1} \equiv \operatorname{Pr}\left(d_{i j, t+1}=1 \mid C_{i j} \in E_{j t}, n_{j t}=1\right)=\frac{\exp \left(\alpha_{j t} u_{i j t}^{G A}+\left(1-\alpha_{j t}\right) u_{i j t}\right)}{\sum_{C_{i j} \in E_{j t}} \exp \left(\alpha_{j t} u_{i j t}^{G A}+\left(1-\alpha_{j t}\right) u_{i j t}\right)} ; \\
p_{i j t}^{2} \equiv \operatorname{Pr}\left(d_{i j, t+1}=1 \mid C_{i j} \in E_{j t}, n_{j t}=2\right)=\frac{2 p_{i j t}^{1}\left(1-p_{i j t}^{1}\right)}{1-\sum_{C_{i j} \in E_{j t}}\left(p_{i j t}^{1}\right)^{2}} .
\end{gathered}
$$

When only one seat is contested in a region, the distributional assumptions on $\varepsilon_{i j t}$ imply that the probability in equation (5) of a single country being elected to the UNSC from $E_{j t}$ follows the conditional logit form. ${ }^{26}$ We then use $p_{i j t}^{1}$ to form equation (6) as the binomial probability of observing a distinct country pair containing $C_{i j}$, where the denominator corrects for the impossibility of a single country obtaining dual membership. Note that, by construction, $\sum_{C_{i j} \in E_{j t}} p_{i j t}^{n_{j t}}=n_{j t}$. Equations (2) and (3) require no further explanation.

Using equations (1)-(5) the likelihood of having observed a given $N P M_{j t}$ of size $n_{j t}\left(L_{i j t}^{n_{j t}}\right)$ is therefore

$$
L_{j t}^{0}=1 ; \quad L_{j t}^{1}=p_{i j t}^{1} ; \quad L_{j t}^{2}=\frac{2 \prod_{C_{i j} \in N P M} p_{i j t}^{1}}{1-\sum_{C_{i j} \in E_{j t}}\left(p_{i j t}^{1}\right)^{2}} ;
$$

where $L_{j t}^{2}$ uses the relevant multinomial distribution to compute the joint probability of having observed a given country pair. The likelihood function for having observed $\left\{N P M_{t}: t \in\{1, \ldots, T\}\right\}$ is then

\footnotetext{
${ }^{26}$ These distributional assumptions are strong but necessary to retain the conditional logit form. Also, when estimating the final likelihood in equation (6), we can allow for the possibility of within-group clustering. Because we model the probability of choosing $C_{i j}$ in year $t$ as conditional on the number of eligible countries in year $t$, our model, like the original conditional logit, implicitly addresses fixed effects for year. For an approach that relaxes our distributional assumptions at some conceptual and computational cost, see Hendel (1999).
} 


$$
\log L=\sum_{j \in J} \sum_{t=1}^{T} \log L_{j t}^{n_{j t}} .
$$

\subsection{Imputation}

Fewer than $3 \%$ of our data points are coded as missing, yet a significant number of countryyears are incomplete for at least one variable $(2,853$ of 5,330). Dropping incomplete countryyears is problematic for both theoretical and practical reasons. From a theoretical perspective, as the probabilities of election in equations $(4,5)$ are functions of the characteristics of every member of the eligible set, artificially excluding a country-year biases the estimates for the remaining countries in that year. From a practical perspective, the sample size becomes unduly small for some regions, leading to a failure of model convergence.

We therefore employ multiple imputation techniques (with ten imputations). ${ }^{27} \mathrm{We}$ impute continuous variables using a truncated regression (to preserve, e.g., non-negativity constraints) that includes as independent variables all those that are fully observed. We similarly impute IMF program participation (the only binary variable with missing observations) with logit.

\subsection{Preference change}

Preferences, both regional and global, may change over time. In particular, Kim and Russett (1996) present evidence of a shift in preferences around the end of the Cold War: voting patterns in the UNGA shifted from an East-West orientation towards a North-South orientation. ${ }^{28}$ Accordingly, we consider two distinct time periods - during and after the Cold War, where we deem the Cold War to end in 1989. We report separate estimates for these

\footnotetext{
${ }^{27}$ The variables with missing values are: United States and Russia voting in the UNGA; debt service; shared regional ideology; control of corruption; and IMF program participation.

${ }^{28}$ Although Voeten's (2000) analysis suggests much subtler changes between the two periods.
} 
two periods for variables where the effects for each period differ.

\subsection{Country-specific effects}

We would like to control for country-specific effects, as outlying countries that exhibit an idiosyncratic effect might drive some results, and obscure others. Indeed, as is observed by Schwartzberg (2003) and Zacher (2004), the UNSC membership data in Table 2 do contain some surprises. In particular, these studies highlight Saudi Arabia, which has never served on the UNSC, or even been nominated, and Panama, which has been a UNSC member unusually often - it served three terms on the UNSC in the sample period (only Brazil and Argentina served more for GRULAC). We are also aware of the case of Mexico, whose participation in the UNSC elections of 2001 marked the end of two decades during which it had adopted a policy of not seeking election to the UNSC (Malone 2000: note 7). ${ }^{29}$

A complication is that a country-specific effect, if present at all, may exist at either the regional or global (UNGA) level, or at both levels. We therefore allow separately for countryspecific effects at the regional and global levels.

\subsection{Model selection}

The discussions above imply that there is a vector of explanatory variables $\mathbf{x}=(\mathbf{s}, \mathbf{s} \times w, \mathbf{c}, \mathbf{r})$ we would like to use to explain UNSC election, where $\mathbf{s}$ denotes the vector of substantive variables relating to the hypotheses discussed in Section 3 (see Table 1), $\mathbf{s} \times w$ denotes the vector of interaction terms between each substantive variable and a Cold War indicator variable, $\mathbf{c}$ is a vector of country indicator variables to be included in the region utility function, and $\mathbf{r}$ is a vector of country indicator variables to be included in the UNGA utility function. Estimating this "full" model is infeasible, however, for $\mathbf{x}$ contains some 436

\footnotetext{
${ }^{29}$ For more on the Mexican case, see, for example, Serrano and Kenny (2006: 298-314). We are grateful to Diego Dewar for this suggestion.
} 
variables, which exhausts the degrees of freedom for certain regions in the earlier years.

Instead, we adopt a model selection procedure that chooses a subvector of the explanatory variables for inclusion in the model. Our approach to model selection reflects a number of factors. First, because the full model cannot be estimated, backward-looking approaches cannot be applied. Second, because of the large number of explanatory variables, methods based upon computing a reasonable criterion for all possible subsets of $\mathbf{x}$ are also infeasible. These two considerations point to a forward-looking approach. As our model is non-linear, however, popular forward-looking algorithms for linear regression, such as the least absolute shrinkage and selection operator (Tibshirani 1996) and least angle regression (Efron et al. 2004), are inapplicable.

We therefore employ a stepwise forward selection procedure that, in each stage, selects one additional variable into the model. In each stage, all elements of $\mathbf{x}$ not already selected into the model are added individually and the t-statistic of each variable is recorded. The variable recording the highest t-statistic is added to the model (and a new stage commenced) if it records statistical significance at the $10 \%$ level. Otherwise, the procedure ends.

We employ this model selection procedure to select two independent models. Model 1 is intended to provide a broad-based analysis of UNSC election in the presence of a full set of control variables. It is selected under the a priori assumption that the elements of $\mathbf{s}$ belong to the model, such that the model selection procedure is applied only to the selection of Cold War interactions and regional and global country-specific effects. Model 2 is a test of the robustness of the substantive variables with respect to model selection, for it is selected without a priori assumptions on inclusion.

A subtlety that arises in the selection of Model 2 is that it is possible that the interaction between a substantive variable and a Cold War indicator is selected into the model, but the 
substantive variable itself is not. Because the interaction variable takes the value of the substantive variable during the Cold War and zero thereafter, this implies that the substantive variable is, in effect, included in the model for the Cold War period only. As it stands, however, there is no means for the selection procedure to include a substantive variable in only the post-Cold War period. In selecting Model 2, we therefore augment $\mathbf{x}$ with a further vector, $\mathbf{s} \times(\mathbf{1}-w)$, which contains the interaction between each substantive variable and a post-Cold War indicator variable.

We also note that, because of the different assumptions maintained in selecting the two models, it is not, in general, expected that the variables selected into Model 2 will form a proper subset of those selected into Model 1. Also, although every variable selected into Model 2 shows statistical significance at $10 \%$ or better in the stage where it is selected, in some cases variables already included in the model may gradually lose statistical significance as further variables are included. Some variables may, therefore, not show statistical significance at the $10 \%$ level in the final model.

\section{Results}

We present two sets of results, both of which are estimated using the likelihood function in equation (6) for UNSC elections between 1970 and 2005. The first set (presented in Table 3a) results from the procedure for Model 1 and thus includes the full set of control variables, as described in the previous section. The second set (presented in Table $3 b$ ) results from the procedure for Model 2 and thus includes the more robust findings, again, as described in the previous section. To match the timing of the election process, we lag the independent variables by one year relative to UNSC membership. We report robust standard errors, adjusted for the imputed data, and clustered on region $\times$ year, thereby allowing for within- 
region and within-year correlation, respectively, and for heteroscedasticity. ${ }^{30} \mathrm{We}$ control for the operation of the Arab swing seat by including an indicator for Arab countries eligible for election to the seat in a given year (see Table 1).

The model selection procedure described in Section 4.7 selects 17 Cold War interaction effects into each of Models 1 and 2, although note that these 17 effects differ between models. In Table 3a, cases where a Cold War interaction is selected show two separate coefficients side-by-side in the relevant column. The left-side coefficient is only for the period during the Cold War, and the right-side coefficient is only for the post-Cold War period.

To present the results in this form, we re-analyzed the final selected model, and, instead of including the substantive variable alongside its interaction variable, we include instead the two interaction variables associated with the substantive variable - one for the interaction with the Cold War indicator and the other for the interaction with the post-Cold War indicator. The coefficients for these two interaction variables are those reported in Table $3 \mathrm{a}$. Hence, the estimated coefficient we obtained for the Cold War interaction variable when included alongside the substantive variable corresponds to the difference between the two coefficients we report. ${ }^{31}$ The interpretation of the results in Table $3 b$ is similar. However, when the selection procedure chooses either the Cold War interaction variable or the post-

\footnotetext{
${ }^{30}$ As in other contexts, we are unable to adjust the standard errors for the effective degrees of freedom used by the model selection procedure itself. As such, it is appropriate to urge caution in the interpretation of findings on the margin of statistical significance at conventional levels. We note the necessity of such model selection, however, given the weak steer provided by theory, and the number of potential explanatory variables.

${ }^{31}$ We do not include a separate Cold War intercept because the conditional logit model has the property that any variable that takes the same value for every country in a group in a particular year (like the Cold War indicator) simply cancels out of the numerator and denominator (see equation 4 and footnote 26 above).
} 
Cold war interaction variable but not the associated substantive variable, two coefficients appear side-by-side, of which one is missing.

The model selection procedure also selects a regional country-specific effect for 16 countries into Model 1, and a global country-specific effect for nine countries. ${ }^{32}$ We include indicator variables for these countries in the model of Table 3a, though, for reasons of space, we do not report their effects in the table. ${ }^{33}$ As well as selecting the known outliers discussed in Section 4.6, the other countries identified as possible outliers include Nigeria, an African country that has pursued an overt policy of queue-jumping (Security Council Report 2009: 6).

As discussed previously, the country-specific effects selected into Model 2 need not correspond to those of Model 1. In practice, however, we observe a high degree of congruence: each of the 16 region country-specific effects allowed for in Model 1 are also selected into Model 2; only one global country-specific effect not selected into Model 1 is selected into Model 2 (the Philippines); and only one global country-specific effect selected into Model 1 is not selected into Model 2 (Egypt).

Before discussing the results, we stress special caution in interpreting the results for Eastern Europe and for the UNGA because of the limited number of observations that each includes. The EE group contains the fewest countries and the most imputed data. And only 36 out of the 180 elections in our sample are contested in the UNGA. ${ }^{34}$

\footnotetext{
32 The regional country-specific effects we allow for are (by region), Africa: Benin, Guinea, Madagascar, Malawi, South Africa, Zimbabwe; Asia: India, Japan, Nepal, Philippines, Saudi Arabia; EE: Bulgaria; the GRULAC: Costa Rica, Mexico, Panama; the WEOG: Austria, Belgium, Switzerland. We allow for a global country-specific effect for Australia, Austria, Burkina Faso, Egypt, Greece, Madagascar, Romania and Slovakia.

${ }^{33}$ These are available in the replication materials.

${ }^{34}$ The estimates for the UNGA in Tables $3 a-b$ seem of a different order of magnitude than the estimates in the regional groups. This can be explained with reference to equation (1), which weights UNGA preferences by $\alpha_{j t}$,
} 


\subsection{Commitment to peace}

Turning to the results, we hypothesize above that a country's commitment to peace should influence UNSC membership because of the explicit guidelines in the UN Charter. We test this hypothesis using a measure of inter- and intra-state conflict, a measure of peace-keeping contributions, and a measure of democracy. At the regional level, we find some evidence to support the commitment-to-peace conjecture, albeit in somewhat different guises in each region. We find no evidence supporting the conjecture at the UNGA level - if anything, we find dictatorships more likely to win contested UNGA elections.

During the Cold War period we find little evidence of an association between UNSC election and engagement in intra- or inter-state conflict. The effect of conflict for the GRULAC is actually positive during the Cold War (in both models). The finding is mainly driven by the nomination of Peru in 1983, which was then engaged in civil conflict with Sendero Luminoso (Shining Path). Note, however, that Barbados contested that election (unsuccessfully) as a second GRULAC candidate. Since the end of the Cold War, Table $3 \mathrm{~b}$ shows that, for Africa and the GRULAC, involvement in an international conflict significantly reduces a country's chances of sitting on the UNSC; for both regions, the negative effect is statistically significant at the $1 \%$ level. The implied marginal effects of the model in Table 3a suggest, for instance, that engagement in conflict reduces the probability of election by around 0.01 in Africa - post-Cold War. ${ }^{35}$ This may seem small, but note that the average election probability

and group preferences by $\left(1-\alpha_{j t}\right)$ in the composite utility function. Even for election years with non-zero values of $\alpha_{j t}$, that coefficient typically is close to zero; $E\left(\alpha_{j t} \mid \alpha_{j t} \neq 0\right)=0.039$, so the apparently large UNGA effects we estimate are offset by the very low weight UNGA preferences receive in the composite preference.

${ }^{35}$ We calculate elasticity and marginal effect estimates for 2005 , the final year of our sample, using equation (4). We evaluate these using the mi predict command in Stata 12, at the group-specific means $\overline{\mathbf{x}}_{j t}$. Different estimates apply to "clean slate" and "contested" elections. The former are evaluated at $\alpha_{j t}=0$, and the latter at 
in Africa for this period was only around 0.05 . Hence, involvement in international conflict cuts this probability by around one-fifth.

The UNGA does not appear to have strong preferences over engagement in conflict: during the sample period it twice elected conflict countries in contested elections: Nicaragua in 1982 and Peru in 1983. In 1993 it also elected Rwanda - then engaged in civil war - in a cleanslate election, but did not elect the other African country on the slate, Guinea-Bissau, which was then not engaged in conflict (see footnote 11 for further details of this election). Overall, in neither time period do we observe a statistically significant effect at the $10 \%$ level.

We also detect a role for peacekeeping troop contributions, although not in every region. Specifically, Table $3 \mathrm{~b}$ shows that in Africa and Asia, the more troops a country contributes, the more likely it is to gain UNSC membership. The effect is significant at the $1 \%$ level in Asia and at the 5\% level in Africa. A 1\% increase in troop contributions is associated with a $0.41 \%$ rise in election probability in Asia, and a $0.19 \%$ rise in election probability in Africa. We find no evidence of a role for troop contributions in EE, the GRULAC, or the WEOG. Peacekeeping contributions do not appear to influence the UNGA either.

Both models indicate that democratic countries in EE and the GRULAC are more likely to be elected in the post-Cold War era. This contrasts with the effect of political regime in these regions during the Cold War, when autocracies were more likely to be selected (although the autocracy effect in Eastern Europe is essentially artifactual - only one country-year is coded as a democracy, namely Poland in 1989). Table 3a also shows that democracy is positively $E_{j}\left(\alpha_{j t} \mid \alpha_{j t} \neq 0\right)$. We find negligible differences between these estimates, however, so we do not report each separately. Estimates also vary according to $n_{j t}$ : we report estimates for $n_{j t}=1$, but in group-years with $n_{j t}=2$, a different estimate based on equation (5) does apply in practice. Last, the estimates vary across years owing to the evolution of the eligible set. We have evaluated the estimates for 2005 under different assumed eligibility conditions, and find this source of variation to be of minor proportions. 
associated with regional nomination in the WEOG. As may be seen from Table $3 b$, this result is driven by the Cold War era, for all countries in the WEOG are coded as democratic in the post-Cold War era. The only authoritarian regime ever elected to represent the WEOG was Spain in 1968. The dictatorships in Portugal and Greece never won election. Since democratizing, Spain has been elected three times, and Portugal and Greece have each been elected twice. Democratic countries are less likely to be elected in the UNGA in Table 3a, but this result may not be robust, as democracy is not selected for the UNGA in Model 2.

\subsection{Foreign aid and debt}

With respect to foreign aid, we find only weak evidence that it plays a role, and not always in a consistent direction. In Table 3a, IMF program participation plays a role in the WEOG, where it is positively associated with election, and in Asia, where it is negatively associated with UNSC election. The IMF has become supremely unpopular in Asia since the East Asian Financial Crisis, so Asian support may genuinely decline for governments cooperating with that institution. Alternatively, IMF program participation might indicate political or economic weakness, reducing the incentives to apply, and the probability of receiving, temporary UNSC membership. Neither of the IMF findings, however, is robust to the stricter selection procedure of Model 2, and IMF program participation is thus not present at all in Table $3 \mathrm{~b}$.

New World Bank projects are positively associated with receiving a regional nomination in Asia in both sets of results. The same finding also holds for the WEOG in Table $3 \mathrm{a}$ (but this effect does not survive in Table 3b) and for Africa during the Cold War in Table $3 b$ (but the effect is not robust to the inclusion of the further control variables in Table 3a). Interestingly, both models indicate that countries with more new World Bank projects are less likely to be elected by the UNGA. As there are contrasting effects at the regional and global levels, it is unclear whether, even in Asia, new World Bank projects have an overall positive effect on election probability. 
US economic assistance plays a role only in the WEOG, where it associates negatively with UNSC election during the Cold War (Table 3b). This result, however, does not hold in the presence of wider controls in Table 3a. A stronger role is found for US military assistance, which, in both sets of results, associates positively with the probability of election by the UNGA. We also find that, during the Cold War, receipt of US military support associated negatively with obtaining a regional nomination in the WEOG. This result is present at the $1 \%$ level in Table 3b, but at only the $10 \%$ level in Table $3 \mathrm{a}$. Table $3 \mathrm{a}$ shows a negative correlation with nomination in Africa, statistically significant at the $10 \%$ level. A final result, seen only in Table $3 \mathrm{~b}$, is that US military assistance is positively associated with regional nomination in EE.

Of interest, more heavily indebted countries are more likely to be elected from Africa and the GRULAC. As debt service contains the most imputed values of our variables, it is sensible to be cautious in interpreting these results. Indeed, the result for the GRULAC holds only in Model 2 (Table 3b), not in the presence of all the control variables. Still, as we find evidence of a turn-taking norm in these regions, governments may have a good idea of when they will get their chance to serve on the UNSC, and thus pursue lax macroeconomic policies in anticipation of the windfall in foreign aid that UNSC membership brings.

\subsection{International power: population, economic development, political ties, and Pariah states}

The finding that US military aid influences contested UNGA elections may indicate that politically powerful countries strategically employ their influence. Further exploring the role of international power, we find that the statistical significance of one of our measures holds across all but one region: the more populous is a country, the more likely it is to take a seat on the UNSC. In both sets of results the statistical significance of the effect holds at least at the $1 \%$ level in all regional groups except EE (although only during the post-Cold War period 
for the GRULAC). The coefficient estimates in Table $3 b$ imply that a $1 \%$ increase in population generates an increase in election probability of between $0.46 \%$ (Africa) and $3.6 \%$ (Asia). Interestingly, however, we find no evidence that the UNGA takes population into account in its voting decisions.

In light of the significance of population, one might expect the statistical significance of a country's level of economic development. We find a robust effect in Africa, Asia and the GRULAC (significant at the 5\% confidence level or better in Table $3 \mathrm{~b}$ ): richer countries in these regions are more likely to gain representation on the UNSC. Territorially large countries are also more likely to obtain a regional nomination in Asia and the GRULAC, as well as in EE, but these findings hold only in Table 3b. The UNGA does not appear to take either income or territorial size into account in its election decisions.

As for political connections to powerful countries, we find no evidence that voting with the United States in the UNGA has an effect on election to the UNSC. Yet, voting with the Soviet Union/Russia is positively associated with gaining group nomination in Africa and the GRULAC (Table 3b). Table $3 b$ further shows that voting with the Soviet Union/Russia is associated with a positive effect in the UNGA, significant at the 5\% level. None of these findings hold, however, in the presence of additional controls in Table 3a.

The "Pariah state" indicator for countries subject to US and/or UN sanctions shows evidence of a change in preferences over time. During the Cold War, sanctioned countries were largely unable to obtain regional nomination, as indicated by the strong negative findings in Africa and Asia. The principal exception was Cuba, which won election from the GRULAC in 1989. Since the Cold War, however, Table $3 \mathrm{~b}$ indicates that sanctions do not predict UNSC election, with the exception of a negative association in the GRULAC. In the post-Cold War period, Nigeria in 1993, Indonesia in 1994, Sudan in 2000, and Syria in 2001 all have obtained a regional nomination. Indonesia and Syria went on to win election in "clean slate" 
votes in the UNGA, Nigeria triumphed in a contested vote, and Sudan lost in a competitive vote.

We also investigate whether membership in particular political groupings influences election to the UNSC. We find evidence that such membership matters in some regions, but not in the UNGA. Moreover, the effects on regional nomination go in different directions. In both models, we see that membership in the G77 - but not in the NAM - has a negative effect in Asia, but a positive effect in the GRULAC. In the GRULAC, dual membership in NAM and G77 also positively predicts regional nomination. No statistically significant effects from OIC membership are found in Table $3 \mathrm{a}$, and it is, unsurprisingly, missing in Table $3 \mathrm{~b}$. Membership in JUSCANZ is included only in the UNGA in Table $3 \mathrm{~b}$, and the estimated positive effect falls short of significance at the $10 \%$ level. As for groupings external to the UN, EU membership appears to raise a country's probability of receiving a regional nomination in EE, but not in the WEOG. NATO membership has a pronounced negative effect on regional nomination probability for members of EE, but has no effect in the WEOG.

\subsection{Culture: colonial heritage, religion, and corruption}

In both sets of results we find evidence that countries with a history of British colonialism enjoy a larger probability of election in Asia, the GRULAC, and the WEOG, but the effect does not hold for Africa or the UNGA. ${ }^{36}$ In contrast, countries with a history of French colonialism do not appear to have greater probabilities of election. Governments sharing a common political ideology with other governments in its region have a greater likelihood of election from EE and the GRULAC according to Table 3b. The finding survives the presence of further controls for the GRULAC but not for EE (table 3a). ${ }^{37}$

\footnotetext{
${ }^{36}$ The former British colonies in the WEOG are Ireland (elected twice) and Malta (elected once).

${ }^{37}$ Note that Potrafke (2009) finds that government ideology affects UNGA voting behavior.
} 
We also consider religion, in particular the proportion of the country's population that is Muslim or Catholic. There are three findings regarding Muslim countries that appear in both sets of results. The first is that in the GRULAC Muslim countries are less likely to be elected to the UNSC in the post-Cold War era. Note that this finding may just be an artifact of the data, however, and not evidence of a real bias against Muslim countries in the GRULAC region. After all, there are only three countries coded as having a significant Muslim population (Suriname: 19.6\%, Guyana 9.0\%, and Trinidad and Tobago 5.9\%). Both Guyana and Trinidad and Tobago served on the UNSC during the Cold-War era, but neither has served in the post-Cold War era.

The second finding is that in the WEOG Muslim countries are less likely to be elected to the UNSC. Here the effect appears driven by one country, Turkey, which never won election to the UNSC during the sample period, but served three earlier terms representing EE and one subsequent term representing the WEOG. The third finding is that Muslim countries are more likely to win in Asia. Membership in the OIC may drive this effect - all Asian countries with significant Muslim populations are OIC members. ${ }^{38}$ In contrast, Asian countries with more Catholics are less likely to win election (the finding holds in both Tables $3 \mathrm{a}$ and $3 \mathrm{~b}$ ). A smaller negative effect is also found in Table $3 \mathrm{~b}$ for Catholic countries in the WEOG, but this result does not hold in the presence of further controls (Table 3a).

The regions appear to have heterogeneous preferences over the control of corruption. We find no role for corruption in Asia or the WEOG. In Africa and the GRULAC, however, we find that corruption pays: the control of corruption has a negative effect (significant at the $10 \%$ and 5\% levels, respectively). Ironically, Africa's commitment to fairness in taking turns may be what makes corruption pay in this region, while in more competitive regions corruption

\footnotetext{
${ }^{38}$ We do not control for OIC in Asia due to collinearity with the Muslim variable. When we do include them together, neither variable is statistically significant.
} 
plays no role because countries disregard turn-taking norms regardless of how corrupt their governments may be. On the other hand, the UNGA has tended to shun more corrupt countries in the post-Cold War era at least according to Table $3 \mathrm{~b}$.

\subsection{The norm of taking turns}

We find widespread evidence of the operation of a turn-taking norm - not only in Africa. The longer a country has been waiting to appear on the Council the higher the probability of receiving the endorsement of the regional caucus. Both models show the importance of the effect at the 5\% significance level or stronger for every region. The estimates in Table $3 \mathrm{~b}$ imply a range of substantive effects across regions: a $1 \%$ increase in waiting time increases election probability by $6.1 \%$ in the WEOG and by $5.7 \%$ in Asia, down to an increase of just $1.8 \%$ in the GRULAC. The common perception that membership on the UNSC rotates therefore finds some support in the electoral patterns at the regional level. As might be expected, the UNGA does not appear to be influenced by the turn-taking rights that apply within the regions.

\section{Conclusion}

The Security Council is the preeminent organ of the United Nations. Membership confers significant international influence and also financial benefits. We thus examine the characteristics of countries that the United Nations Security Council (UNSC) election process rewards. To that end, we consider five different perspectives as to the determinants of election to the UNSC.

As candidature decisions at the regional level follow no codified rules (with the exception of Africa) and governments keep their negotiations behind closed doors, many factors likely remain unobserved. It is thus appropriate to treat our results with caution. Nevertheless, if 
election to the UNSC were entirely random, we would not expect the types of systematic relationships we report in Section 5.

Our results suggest that the regional nomination process tends to allocate membership according to a compromise between a norm to elect more powerful countries - populous countries from throughout the world and richer countries from Africa, Asia, and the Latin America and Caribbean Group (GRULAC - el Grupo Latinoamericano y Caribeño) - and a norm for each country to receive a turn. Mediating this central compromise are a norm against nominating countries involved in civil or international war (in post-Cold War Africa and the GRULAC) and one in favor of countries that contribute more personnel to UN peacekeeping missions (in Africa and Asia). During the Cold War, the regions of Africa and Asia may have followed a norm against nominating pariah countries whose presence on the UNSC would have upset one or more of the permanent members. If so, the norm seems to have weakened or disappeared in these regions during the post-Cold War era, and it may have emerged in the GRULAC.

The United Nations General Assembly (UNGA) has the opportunity to participate meaningfully in the UNSC election process in around only one election in five. When it does have a say, we see some evidence of the influence of powerful countries. Governments receiving US military aid are more likely to win contested elections, while countries voting with the Soviet Union/Russia in the UNGA also win contested elections more frequently. The UNGA appears less likely, however, to select countries heavily reliant on projects funded multilaterally through the World Bank. Since the end of the Cold War, the UNGA has also systematically directed membership away from countries perceived as having high levels of corruption. In contrast to the regional groups, however, UNGA decisions do not appear to be influenced by regional turn-taking norms or by a country's population or income. Broadly 
speaking, there is a lack of consistent evidence across regions and the UNGA for a role of foreign aid, and only occasional and heterogeneous evidence for cultural influences.

These findings speak to literatures on the determinants and consequences of foreign aid, the broad effects armed conflict, the evolution of norms, and, of course, the research on the UNSC itself. Because Security Council participation is consequential for different types of foreign aid, a heterogeneous election process implies that UNSC membership may serve as an instrument for international political importance. We caution, however, that our results at least suggest the importance of controlling for population and income. We stress here that turn-taking is likely an exogenous source of variation that scholars can use, and it has a statistically significant effect for the $80 \%$ of the sample, where regions make the decision. Turn-taking, however, does not hold for the UNGA, so scholars may wish to flag the contested elections ( $20 \%$ of the sample).

As the first detailed empirical analysis of the determinants of UNSC election, our study represents an initial step. In the future, researchers may seek to augment country-level data with personal-level data on UN Ambassadors. Malone (2000), citing Dutch officials, notes that up to a quarter of UN representatives vote without instructions from their capitals. The personal characteristics and interactions of the individuals on the New York scene may therefore play a critical role.

As for reform of the UNSC, we propose considering what currently determines representation: election depends partly on a random draw of idiosyncratic factors, partly on how powerful a country is in terms of population and income, and partly on a norm of giving everyone a turn. If powerful countries should run for UNSC seats more often - perhaps because they play a crucial role in global politics - we should push for more UNGA involvement, as we find no evidence of a turn-taking norm when the UNGA decides contested elections. Allowing for reelection, for example, would enable powerful countries to 
run for election more often. If, on the other hand, every country should have its turn on the world stage, we should endow the regional groups with the power to elect their own representatives because all regions follow the turn-taking norm to an extent. Alternatively, one could ensure turn-taking by selecting through the actual rotation of UN members. We suspect that interests on both sides - those in favor of powerful countries and those in favor of taking turns - counterbalance each other so that the status quo is likely to prevail.

\section{References}

African Union (2006). Rules of procedure of the AU Ministerial Committee on candidatures within the international system. EX.CL/213 (VIII), Addis Ababa: African Union.

Bailey, S., \& Daws, S. (1998). The procedure of the UN Security Council. Oxford: Oxford University Press.

Bashir, O. S. \& Lim, D. J. (2013). Misplaced blame: Foreign aid and the consequences of UN Security Council membership. Journal of Conflict Resolution, 57(3), 509-523.

Beck, T., Clarke, G., Groff, A., Keefer, P., \& Walsh, P. (1999). New tools and new tests in comparative political economy: The Database of Political Institutions. Development Research Group, World Bank.

Besley, T., \& Reynal-Querol, M. (2011). Do democracies select more educated leaders? American Political Science Review, 105(3), 552-566.

Bruhn, M., \& Gallego, F. A. (2012). Good, bad, and ugly colonial activities: do they matter for economic development? Review of Economics and Statistics, 94(2), 433-461.

Bueno de Mesquita, B., \& Smith, A. (2010). The pernicious consequences of UN Security Council membership. Journal of Conflict Resolution, 54(5), 667-686.

Chapman, T. L. (2011). Securing approval: Domestic politics and multilateral authorization for war. Chicago: University of Chicago Press. 
Cheibub, J., Gandhi, J., \& Vreeland, J. R. (2010). Democracy and dictatorship revisited. Public Choice, 143(1-2), 67-101.

Colman, A. M., \& Browning, L. (2009). Evolution of cooperative turn-taking. Evolutionary Ecology Research, 11(6), 949-963.

Combs, J. A. (2012). Embargoes and sanctions. In Paul Finkelman (Ed.) Encyclopedia of the new American nation. Michigan: Gale.

Conway, P. (2007). The revolving door: Duration and recidivism in IMF programs. Review of Economics and Statistics, 89(2), 205-220.

Costa Rica (2005). Note verbale dated 20 July 2005 from the Permanent Mission of Costa Rica to the United Nations addressed to the Secretary-General, A/59/881. New York: United Nations.

Daws, S. (1999). The origins and development of UN electoral groups. In R. Thakur (Ed.) What is equitable geographic representation in the 21st century? (pp. 11-29). Tokyo: United Nations University.

de Vries, C., Steenbergen, M. R., \& Hangartner, D. (2009). A choice set modeling approach to EU issue voting. Paper presented at the EUSA Conference, Los Angeles.

Dowding, K. M., Goodin, R. E. \& Pateman, C. (2004). Justice and democracy: Essays for Brian Barry. Cambridge: Cambridge University Press.

Dreher, A., \& Sturm, J.-E. (2012). Do the IMF and the World Bank influence voting in the UN General Assembly? Public Choice, 151(1-2), 363-397.

Dreher, A., Sturm, J.-E., \& Vreeland, J. R. (2009a). Development aid and international politics: Does membership on the UN Security Council influence World Bank decisions? Journal of Development Economics, 88(1), 1-18.

Dreher, A., Sturm, J.-E., \& Vreeland, J. R. (2009b). Global horse trading: IMF loans for votes in the United Nations Security Council. European Economic Review, 53(7), 742-757. 
Dreher, A., Sturm, J.-E., \& Vreeland, J. R. (2010). Does membership on the UN Security Council influence IMF conditionality? Courant Research Centre, Poverty, Equity and Growth Discussion Paper 36.

Dreher, A., \& Vreeland, J. R. (2009). Idiosyncratic election to the United Nations Security Council. Working Paper.

Efron, B., Hastie, T., Johnstone, I., \& Tibshirani, R. (2004). Least angle regression. Annals of Statistics, 32(2), 407-499.

Estonia (2011) Estonia in the United Nations. Tallinn: Estonian Ministry of Foreign Affairs. Available: http://www.vm.ee/?q=en/node/4088.

Fehr, E., \& Schmidt, K. (1999). A theory of fairness, competition and cooperation. Quarterly Journal of Economics, 114(3), 817-868.

Ferejohn, J., \& Rosenbluth, F. M. (2008). Warlike democracies. Journal of Conflict Resolution, 52(1), 3-38.

Franz, M., van der Post, D., Schülke, O., \& Ostner, J. (2011). The evolution of cooperative turn-taking in animal conflict. BMC Evolutionary Biology, 11: 323.

Glasgow, G., Golder, M., \& Golder, S. N. (2012). New empirical strategies for the study of parliamentary government formation. Political Analysis, 20(2), 248-270.

Golder, M., Golder, S. N., \& Siegel, D. A. (2012). Modeling the institutional foundations of parliamentary government formation. Journal of Politics, 74(2), 427-445.

Hamermesh, D. S., \& Schmidt, P. (2003). The determinants of Econometric Society fellows elections. Econometrica, 71(1), 399-407.

Heldt, B. (2008). Personnel contributions to UN peacekeeping operations, 1970-2005. Folke Bernadotte Academy, Stockholm.

Hendel, I. (1999). Estimating multiple-discrete choice models: An application to computerization returns. Review of Economic Studies, 66(2), 423-446. 
Hollyer, J. R., Rosendorff, B. P., \& Vreeland, J. R. (2011). Democracy and transparency. Journal of Politics, 73(4), 1191-1205.

Hosli, M. O., Moody, R., O’Donovan, B., Kaniovski, S., \& Little, A. C. H. (2011). Squaring the circle? Collective and distributive effects of United Nations Security Council reform. Review of International Organizations, 6(2), 163-187.

Hurd, I. (2007). After anarchy: Legitimacy and power in the UN Security Council. Princeton: Princeton University Press.

Iwanami, Y. (2012). Delegating the power to govern security affairs: The composition of the UN Security Council. Paper presented at the $5^{\text {th }}$ Annual Conference on the Political Economy of International Organizations, Villanova.

Iyer, L. (2010). Direct versus indirect colonial rule in India: Long-term consequences. Review of Economics and Statistics, 92(4), 693-713.

Jayakumar, S. (2011). Diplomacy: A Singapore experience. Singapore: Straits Times Press.

Kaufmann, D., Kraay, A., \& Mastruzzi, M. (2011). The Worldwide Governance Indicators: Methodology and analytical issues. Hague Journal on the Rule of Law, 3(2), 220-246.

Kilby, C. (2009). The political economy of conditionality: An empirical analysis of World Bank loan disbursements. Journal of Development Economics, 89(1), 51-61.

Kilby, C. (2013). An empirical assessment of informal influence in the World Bank. Economic Development and Cultural Change, 61(2), 431-464.

Kim, S. Y., \& Russett, B. (1996). The new politics of voting alignment in the United Nations General Assembly. International Organization, 50(4), 629-652.

Kuziemko, I., \& Werker, E. (2006). How much is a seat on the Security Council worth? Foreign aid and bribery at the United Nations. Journal of Political Economy, 114(5), 905930. 
Levy, P. I. (1999). Sanctions on South Africa: What did they do? Yale University, Economic Growth Center, Center Discussion Paper No. 796.

Lim, D., \& Vreeland, J. R. (2013). Regional organizations and international politics: Japanese influence over the Asian Development Bank and the UN Security Council. World Politics, 65(1), 34-72.

Luck, E. C. (2006). The UN Security Council: Practice and promise. New York: Routledge.

Malone, D. M. (1998). Decision-making in the UN Security Council: The case of Haiti, 19901997. New York: Oxford University Press.

Malone, D. M. (2000). Eyes on the prize: The quest for nonpermanent seats on the UN Security Council. Global Governance, 6(1), 3-23.

Manski, C., \& Sherman, L. (1980). An empirical analysis of household choice among motor vehicles. Transportation Research Part A: General, 14(5-6), 349-366.

McFadden, D. L. (1973). Conditional logit analysis of qualitative choice behavior. In P. Zarambeka (Ed.) Frontiers in econometrics (pp. 105-142). New York: Academic Press.

Morgan, T. C., Krustev, V., \& Bapat, N. A. (2006). Threat and imposition of sanctions (TIES) data user's manual: Case level data. Available: http://www.unc.edu/ bapat/TIES.htm.

New Zealand (2012). United Nations handbook 2012-13. Wellington: Ministry of Foreign Affairs and Trade.

Nogee, J. L. (2004). Yalta conference. In James R. Millar (Ed.) Encyclopedia of Russian history, Vol. 4. Macmillan Reference USA: New York.

Potrafke, N. (2009). Does government ideology influence political alignment with the US? An empirical analysis of voting in the UN General Assembly. Review of International Organizations, 4(3), 245-268. 
Przeworski, A., Alvarez, M., Cheibub, J. A., \& Limongi, F. (2000). Democracy and development: Political regimes and economic well-being in the world, 1950-1990. New York: Cambridge University Press.

Rajan, R. G., \& Subramanian, A. (2008). Aid and Growth: What does the cross-country evidence really show? Review of Economics and Statistics, 89(2), 205-220.

Rawls, J. (1971). A theory of justice. Cambridge, MA: Harvard University Press.

Reynaud, J., \& Vauday, J. (2009). Geopolitics in the International Monetary Fund. Journal of Development Economics, 89(1), 139-162.

Russett, B., \& Oneal, J. R. (2001). Triangulating peace: Democracy, interdependence, and international organizations. New York: W. W. Norton.

Scharioth, N. (2010). Western democracies in the UN: Who gets elected and why - a quantitative examination of elections to United Nations councils and committees. Berlin: Nomos.

Schmitz, J., \& Schwarze, J. (2012). Behind the scenes - what determines elections of nonpermanent members to the UNSC? An empirical analysis. Paper presented at the $5^{\text {th }}$ Annual Conference on the Political Economy of International Organizations, Villanova.

Schwartzberg, J. E. (2003). Entitlement quotients as a vehicle for United Nations reform. Global Governance, 9(1), 81-114.

Security Council Report (2009). Special research report no. 1: UN Security Council elections 2009. New York: Security Council Report.

Security Council Report (2011). Special research report no. 4: Security Council elections 2011. New York: Security Council Report. Available: www.securitycouncilreport.org.

Serrano, M., \& Kenny, P. (2006). Iraq and world order: A Latin American perspective. In R. Thakur \& W. P. S. Sidhu (Eds.) The Iraq crisis and world order (pp. 298-314). Tokyo: United Nations University Press. 
Stone, R. W. (2002). Lending credibility: The International Monetary Fund and the postcommunist transition. Princeton: Princeton University Press.

Strezhnev, A., \& Voeten, E. (2012). United Nations General Assembly voting data. Available: http://hdl.handle.net/1902.1/12379.

Themnér, L., \& Wallensteen, P. (2012). Armed conflicts, 1946-2011. Journal of Peace Research, 49(4), 565-575.

Tibshirani, R. (1996). Regression shrinkage and selection via the Lasso. Journal of the Royal Statistical Society. Series B (Methodological), 58(1), 267-288.

UN (2012). United Nations Regional Groups of Member States. New York: UN. Available: http://www.un.org/depts/DGACM/RegionalGroups.shtml.

USAID (2011). U.S. overseas loans and grants: Obligations and loan authorizations. Washington DC: USAID. Available: http://gbk.eads.usaidallnet.gov/about/

Voeten, E. (2000). Clashes in the Assembly. International Organization, 54(2), 185-215.

Voeten, E. (2001). Outside options and the logic of Security Council action. American Political Science Review, 95(4), 845-858.

Zacher, M. W. (2004). The conundrums of international power sharing. In R. M. Price \& M. W. Zacher (Eds.) The United Nations and global security (pp. 211-225). New York: Palgrave Press. 
Table 1: Potential determinants of UNSC election

Do governments practice a turn-taking norm, rotating membership through eligible candidates?

Turn-taking norm

Number of years since most recently becoming eligible for election to the UNSC divided by number of other countries eligible (author calculations).

Does foreign aid determine election?

IMF program participation

Indicator coded 1 if a country participated in an IMF program for at least five months in a year, 0 otherwise (http://axel-dreher.de/Dreher\%20IMF\%20and\%20WB.xls).

New World Bank projects

Number of new World Bank projects starting during the year

(http://axel-dreher.de/Dreher\%20IMF\%20and\%20WB.xls, coded as in Dreher et al. 2009a).

US Economic Aid (log)

US Military Aid (log)

Log (plus 1) of US economic aid going to the country in constant \$US (USAID 2011).

Debt service

Log (plus 1) of US military aid going to the country in constant \$US (USAID 2011).

Debt service as a percentage of gross national income (World Bank).

Is election driven by international power or relationships with powerful countries?

Population (log)

GNI per capita $(\log )$

Log of population (UN Statistics Division).

Territory $(\log )$

Log of real GNI per capita in \$US (UN Statistics Division).

Pariah state

Log of territorial size in square kilometers (CIA Factbook).

US voting in UNGA

Indicator coded 1 if a country is subject to UN/US sanctions (Morgan et al. 2006). ${ }^{1}$

Voting in line with the United States at the UNGA $-\%$ all votes the same; abstain $=0.5$

(Strezhnev and Voeten 2012; coded as in Dreher and Sturm 2012).

USSR/Russia voting in UNGA Voting in line with the Soviet Union/Russia at the UNGA - \% all votes the same; abstain = 0.5 (Strezhnev and Voeten 2012; coded as in Dreher and Sturm 2012).

OIC

Indicator coded 1 if a country is a member of OIC, 0 otherwise (http://www.oic-oci.org/).

JUSCANZ

Indicator coded 1 if a country is a member of JUSCANZ, 0 otherwise.

(http://www.eyeontheun.org/view.asp?p=55\&l=11).

G77 only

Indicator coded 1 if a country is a member of the G77 and not a member of NAM, 0 otherwise (http://www.g77.org/).

NAM only

G77 and NAM

Indicator coded 1 if a country is a member of NAM and not a member of the G77, 0

otherwise (http://www.nam.gov.za/).

EU

Indicator coded 1 if a country is a member of the G77 and NAM, 0 otherwise.

Indicator coded 1 if a country is a member of EU, 0 otherwise (http://www.europa.eu/).

NATO

Indicator coded 1 if a country is a member of NATO, 0 otherwise (http://www.nato.int/).

Do governments follow a norm of choosing countries committed to peace?

\section{Conflict}

Peacekeeping troops $(\log )$

Democracy indicator

Control of corruption

Indicator coded 1 if a country is engaged in a conflict, 0 otherwise (Themnér and Wallensteen 2012).

Log (plus 1) of the average monthly military manpower supplied to UN peacekeeping operations per year (Heldt 2008).

Indicator coded 1 if contested elections fill the executive and legislative branches of government, 0 otherwise (Cheibub et al. 2010).

Score indicating perceptions of the extent to which public power is exercised for private gain (Kaufmann et al. 2011).

Do shared cultural traits play a role?

Muslim (\%)

Catholic (\%)

Shared regional ideology

Former British colony

Former French colony
Muslims as a proportion of the total population, time invariant (Przeworski et al. 2000). Catholics as a proportion of the total population, time invariant (Przeworski et al. 2000). Proportion of the chief executives in the region sharing the same political ideology - left, center, right (Beck et al. 1999). Coded 0 for non-ideological governments.

Indicator coded 1 if a country is a former British colony, 0 otherwise (Przeworski et al. 2000).

Indicator coded 1 if a country is a former French colony, 0 otherwise (Przeworski et al. 2000).

Controls

Arab seat
Indicator for Arab countries eligible for election to the Arab swing seat (coded 1 for Arab countries in Africa every fourth year beginning 1972; 1 for Arab countries in Asia every fourth year beginning 1970; 0 otherwise).

\footnotetext{
${ }^{1}$ We code a country-year observation as a "pariah" if it is subject to sanctions imposed by the United States and/or conducted through the United Nations (through the Security Council or General Assembly). We do not code country-years as "pariahs" if (1) sanctions target trade practices, (2) the anticipated costs are not coded as "major" or "severe" (so, we only consider pariahs as those under "major" and/or "severe" sanctions), or (3) the country acquiesced to demands before sanctions were imposed or capitulated at the threat stage. We use the 2009 updated version of the Morgan et al. (2006) dataset (TIES version 3.5), which covers 1971-2008. We extend the data by including four major sanctions episodes, which begin before 1971: Cuba (1960-present), North Korea (1950-present), South Africa (1963-1994) and Vietnam (1954-1994). For a discussion of these additional cases see Combs (2012) and Levy (1999). Our main findings on the pariah variable hold, however, whether or not we include these additional sanctions episodes.
} 
Table 2: UNSC Membership (terms held 1971-2006)

\begin{tabular}{|c|c|c|c|c|c|c|c|c|c|}
\hline \multicolumn{2}{|l|}{ Africa } & \multicolumn{2}{|l|}{ Asia } & \multicolumn{2}{|l|}{$\mathrm{EE}$} & \multicolumn{2}{|l|}{ GRULAC } & \multicolumn{2}{|c|}{ WEOG } \\
\hline Algeria & 2 & Japan & 7 & Romania & 3 & Argentina & 5 & Germany $^{5}$ & 4 \\
\hline Benin & 2 & India & 4 & Bulgaria & 2 & Brazil & 4 & Italy & 4 \\
\hline Cameroon & 2 & Pakistan & 4 & Poland & 2 & Panama & 3 & Canada & 3 \\
\hline Congo & 2 & Bangladesh & 2 & Ukraine $^{6}$ & 2 & Peru & 3 & Spain & 3 \\
\hline Democratic Rep. of the Congo & 2 & Indonesia & 2 & Yugoslavia $^{4}$ & 2 & Venezuela & 3 & Australia & 2 \\
\hline Egypt & 2 & Malaysia & 2 & Belarus $^{6}$ & 1 & Chile & 2 & Austria & 2 \\
\hline Gabon & 2 & Philippines & 2 & Czechoslovakia $^{3}$ & 1 & Colombia & 2 & Belgium & 2 \\
\hline Ghana & 2 & Bahrain & 1 & Czech Republic ${ }^{3}$ & 1 & Costa Rica & 2 & Denmark & 2 \\
\hline Guinea & 2 & Iraq & 1 & East Germany $^{5}$ & 1 & Guyana & 2 & Ireland & 2 \\
\hline Kenya & 2 & Jordan & 1 & Hungary & 1 & Jamaica & 2 & Netherlands & 2 \\
\hline Mauritius & 2 & Kuwait & 1 & Slovakia $^{3}$ & 1 & Mexico & 2 & Norway & 2 \\
\hline Nigeria & 2 & Nepal & 1 & Slovenia $^{4}$ & 1 & Bolivia & 1 & Portugal & 2 \\
\hline Tunisia & 2 & Oman & 1 & Albania & 0 & Cuba & 1 & Sweden & 2 \\
\hline United Rep. of Tanzania & 2 & Qatar & 1 & Armenia & 0 & Ecuador & 1 & Finland & 1 \\
\hline Zambia & 2 & Rep. of Korea & 1 & Azerbaijan & 0 & Honduras & 1 & Greece & 1 \\
\hline Zimbabwe & 2 & Singapore & 1 & Bosnia \& Herzegovina ${ }^{4}$ & 0 & Nicaragua & 1 & Malta & 1 \\
\hline Angola & 1 & Syrian Arab Rep. & 1 & Croatia $^{4}$ & 0 & Trinidad \& Tobago & 1 & New Zealand & 1 \\
\hline Botswana & 1 & Thailand & 1 & Estonia & 0 & Antigua \& Barbuda & 0 & Andorra & 0 \\
\hline Burkina Faso & 1 & United Arab Emirates & 1 & Georgia & 0 & Barbados & 0 & Iceland & 0 \\
\hline Cape Verde & 1 & Yemen $^{1}$ & 1 & Latvia & 0 & Bahamas & 0 & Israel $^{7}$ & 0 \\
\hline Cote d'Ivoire & 1 & Afghanistan & 0 & Lithuania & 0 & Belize & 0 & Liechtenstein & 0 \\
\hline Djibouti & 1 & Bhutan & 0 & Rep. of Moldova & 0 & Dominica & 0 & Luxembourg & 0 \\
\hline Ethiopia $^{2}$ & 1 & Brunei & 0 & Serbia \& Montenegro 4 & 0 & Dominican Rep. & 0 & Monaco & 0 \\
\hline Gambia & 1 & Cambodia & 0 & TFYR Macedonia ${ }^{4}$ & 0 & El Salvador & 0 & San Marino & 0 \\
\hline Guinea-Bissau & 1 & Cyprus & 0 & & & Grenada & 0 & Switzerland & 0 \\
\hline Libya & 1 & DPR Korea & 0 & & & Guatemala & 0 & Turkey & 0 \\
\hline Mali & 1 & Fiji & 0 & & & Haiti & 0 & & \\
\hline Madagascar & 1 & Iran & 0 & & & Paraguay & 0 & & \\
\hline Mauritania & 1 & Kazakhstan & 0 & & & St Lucia & 0 & & \\
\hline Morocco & 1 & Kyrgyzstan & 0 & & & St Vincent \& the Grenadines & 0 & & \\
\hline Namibia & 1 & Laos & 0 & & & St Kitts \& Nevis & 0 & & \\
\hline Niger & 1 & Lebanon & 0 & & & Suriname & 0 & & \\
\hline Rwanda & 1 & Marshall Islands & 0 & & & Uruguay & 0 & & \\
\hline Senegal & 1 & Maldives & 0 & & & & & & \\
\hline Somalia & 1 & Micronesia & 0 & & & & & & \\
\hline Sudan & 1 & Mongolia & 0 & & & & & & \\
\hline Togo & 1 & Myanmar & 0 & & & & & & \\
\hline Uganda & 1 & Nauru & 0 & & & & & & \\
\hline Burundi & 0 & Palau & 0 & & & & & & \\
\hline Central African Rep. & 0 & Papua New Guinea & 0 & & & & & & \\
\hline Chad & 0 & Saudi Arabia & 0 & & & & & & \\
\hline Comoros & 0 & Samoa & 0 & & & & & & \\
\hline Equatorial Guinea & 0 & Solomon Islands & 0 & & & & & & \\
\hline Eritrea $^{2}$ & 0 & Sri Lanka & 0 & & & & & & \\
\hline Lesotho & 0 & Tajikistan & 0 & & & & & & \\
\hline Liberia & 0 & Timor L'este & 0 & & & & & & \\
\hline Malawi & 0 & Tonga & 0 & & & & & & \\
\hline Mozambique & 0 & Tuvalu & 0 & & & & & & \\
\hline Sao Tome \& Principe & 0 & Turkmenistan & 0 & & & & & & \\
\hline Seychelles & 0 & Uzbekistan & 0 & & & & & & \\
\hline Sierra Leone & 0 & Vanuatu & 0 & & & & & & \\
\hline South Africa & 0 & Vietnam & 0 & & & & & & \\
\hline Swaziland & 0 & Yemen Arab Rep. ${ }^{1}$ & 0 & & & & & & \\
\hline
\end{tabular}

${ }^{1}$ People's Democratic Republic of Yemen and Yemen Arab Republic were separate members of the UN until 1990 when the two countries united as the single member Yemen.

${ }^{2}$ Eritrea was part of Ethiopia until around 1991. Eritrea officially joined the UN as a separate member in 1993 and Ethiopia retained its membership of the UNGA.

${ }^{3}$ Czechoslovakia dissolved in 1992. The Czech Republic and Slovakia joined as separate members in 1993.

${ }^{4}$ Yugoslavia dissolved in 1992, being replaced by separate membership in EE for Bosnia \& Herzegovina, Croatia, Slovenia, TFYR Macedonia and Serbia \& Montenegro.

${ }^{5}$ East Germany was a member in EE and West Germany a member in the WEOG. On 3 October 1990, the two German states united to form one sovereign state. Since reunification, West Germany has acted in the UN under the designation "Germany" (New Zealand 2012). Hence, two of the four terms attributed to "Germany" were served as "West Germany," and two as "Germany."

${ }^{6}$ Although only gaining full independence in 1991, Ukraine and Belarus were founding members of the UN, having separate membership from the USSR. According to Nogee (2004), this arrangement was agreed between the UK, USA and USSR at the Yalta Convention in 1945, so as to give the USSR three votes in the UNGA.

${ }^{7}$ Israel joined the UN in 1949 but only became a temporary member in the WEOG (and thus eligibility for election to the UNSC) in 2000. 
Table 3a: Model 1

\begin{tabular}{|c|c|c|c|c|c|c|c|c|c|c|c|}
\hline \multirow[t]{2}{*}{ Variables } & \multicolumn{2}{|c|}{ Africa } & \multicolumn{2}{|c|}{ Asia } & EE & \multicolumn{2}{|c|}{ GRULAC } & \multicolumn{2}{|c|}{ WEOG } & \multicolumn{2}{|c|}{ UNGA } \\
\hline & $\leq 1989$ & $>1989$ & $\leq 1989$ & $>1989$ & $\leq 1989 \quad>1989$ & $\leq 1989$ & $>1989$ & $\leq 1989$ & $>1989$ & $\leq 1989$ & $>1989$ \\
\hline Turn-taking norm & \multicolumn{2}{|c|}{$\begin{array}{c}4.90^{* * *} \\
(0.98)\end{array}$} & \multicolumn{2}{|c|}{$\begin{array}{c}7.81^{* * *} \\
(2.15)\end{array}$} & $\begin{array}{c}1.74^{* * * *} \\
(0.66)\end{array}$ & \multicolumn{2}{|c|}{$\begin{array}{c}1.69^{* *} \\
(0.76)\end{array}$} & \multicolumn{2}{|c|}{$\begin{array}{c}7.61^{* * *} \\
(2.05)\end{array}$} & \multicolumn{2}{|c|}{$\begin{array}{l}-6.81 \\
(10.49)\end{array}$} \\
\hline GNI per capita (log) & $\begin{array}{l}0.30 \\
(0.41)\end{array}$ & $\begin{array}{c}1.35^{* * *} \\
(0.32)\end{array}$ & \multicolumn{2}{|c|}{$\begin{array}{l}1.36^{* *} \\
(0.56)\end{array}$} & $\begin{array}{l}-1.03 \\
(1.04)\end{array}$ & \multicolumn{2}{|c|}{$\begin{array}{c}1.38^{* * *} \\
(0.50)\end{array}$} & \multicolumn{2}{|c|}{$\begin{array}{l}2.83 \\
(2.14)\end{array}$} & \multicolumn{2}{|c|}{$\begin{array}{c}4.21 \\
(14.16)\end{array}$} \\
\hline Population (log) & \multicolumn{2}{|c|}{$\begin{array}{c}0.75^{* * *} \\
(0.26)\end{array}$} & \multicolumn{2}{|c|}{$\begin{array}{l}4.35^{* * *} \\
(1.19)\end{array}$} & $\begin{array}{l}0.65 \\
(2.08)\end{array}$ & $\begin{array}{l}0.61 \\
(0.57)\end{array}$ & $\begin{array}{c}1.32^{* * *} \\
(0.51)\end{array}$ & \multicolumn{2}{|c|}{$\begin{array}{l}5.81^{* * *} \\
(1.71)\end{array}$} & \multicolumn{2}{|c|}{$\begin{array}{l}16.56 \\
(11.52)\end{array}$} \\
\hline Territory (log) & \multicolumn{2}{|c|}{$\begin{array}{l}-0.15 \\
(0.19)\end{array}$} & \multicolumn{2}{|c|}{$\begin{array}{l}-0.60 \\
(0.42)\end{array}$} & $\begin{array}{l}1.78 \\
(2.45)\end{array}$ & \multicolumn{2}{|c|}{$\begin{array}{l}0.58 \\
(0.37)\end{array}$} & \multicolumn{2}{|c|}{$\begin{array}{l}-1.15 \\
(0.74)\end{array}$} & \multicolumn{2}{|c|}{$\begin{array}{r}-9.27 \\
(8.48)\end{array}$} \\
\hline USA voting in the UNGA & \multicolumn{2}{|c|}{$\begin{array}{l}-2.35 \\
(5.24)\end{array}$} & \multicolumn{2}{|c|}{$\begin{array}{l}5.73 \\
(5.92)\end{array}$} & $\begin{array}{l}-1.02 \\
(8.73)\end{array}$ & & .04 & $\begin{array}{l}-24 \\
(14\end{array}$ & $\begin{array}{l}.14 \\
58)\end{array}$ & & $\begin{array}{l}5.71 \\
4.63)\end{array}$ \\
\hline Russia voting in the UNGA & & $\begin{array}{l}53 \\
79)\end{array}$ & $\begin{array}{l}6.7 \\
(4.5\end{array}$ & & $\begin{array}{l}-7.89 \\
(12.05)\end{array}$ & & .30 & & $\begin{array}{l}95 \\
27)\end{array}$ & & $\begin{array}{l}2.27 \\
3.50)\end{array}$ \\
\hline Pariah state & $\begin{array}{l}-15.54^{* * *} \\
(2.01)\end{array}$ & $\begin{array}{l}-0.54 \\
(1.80)\end{array}$ & $\begin{array}{l}-20.50^{* * * *} \\
(2.96)\end{array}$ & $\begin{array}{l}0.66 \\
(1.22)\end{array}$ & - & $\begin{array}{l}-1.05 \\
(1.70)\end{array}$ & $\begin{array}{c}-10.29^{* * * *} \\
(2.65)\end{array}$ & - & - & & $\begin{array}{l}.51 \\
3.40)\end{array}$ \\
\hline IMF program participation & & $\begin{array}{l}67 \\
57)\end{array}$ & $\begin{array}{r}-1.4 \\
(0.7\end{array}$ & & $\begin{array}{l}1.75 \\
(1.39)\end{array}$ & & .32 & $\begin{array}{l}4.6 \\
(2 .\end{array}$ & 3. & & 0.31 \\
\hline New World Bank projects & & $\begin{array}{l}18 \\
13)\end{array}$ & $\begin{array}{r}0.2 \\
(0.1\end{array}$ & & $\begin{array}{l}-0.21 \\
(0.28)\end{array}$ & & $\begin{array}{l}.03 \\
.08)\end{array}$ & $\begin{array}{r}4.0 \\
(1 .\end{array}$ & $\begin{array}{l}7^{* * *} \\
47)\end{array}$ & & $\begin{array}{l}.34^{* *} \\
.55)\end{array}$ \\
\hline US economic aid (log) & & $\begin{array}{l}03 \\
04)\end{array}$ & $\begin{array}{l}0.0 \\
(0.0\end{array}$ & & $\begin{array}{l}-0.07 \\
(0.10)\end{array}$ & & $\begin{array}{l}.09 \\
.06)\end{array}$ & $\begin{array}{l}-0.25 \\
(0.18)\end{array}$ & $\begin{array}{l}-0.005 \\
(0.08)\end{array}$ & & $\begin{array}{l}.49 \\
.22)\end{array}$ \\
\hline US military aid (log) & & $\begin{array}{l}08^{*} \\
04)\end{array}$ & $\begin{array}{l}0.0 \\
(0.0\end{array}$ & & $\begin{array}{l}0.42 \\
(0.33)\end{array}$ & & .01 & $\begin{array}{c}-0.26^{*} \\
(0.15)\end{array}$ & $\begin{array}{l}0.03 \\
(0.11)\end{array}$ & & $\begin{array}{l}3^{* * *} \\
.10)\end{array}$ \\
\hline Debt service (\% GNI) & & 1) & $\begin{array}{l}0.0 \\
(0.6\end{array}$ & & $\begin{array}{r}-0.49 \\
(0.84)\end{array}$ & & $\begin{array}{l}.82 \\
.59)\end{array}$ & $\begin{array}{l}-0 \\
(0 .\end{array}$ & & & $\begin{array}{l}.85 \\
2.11)\end{array}$ \\
\hline OIC & & $\begin{array}{l}28 \\
75)\end{array}$ & - & & - & & - & - & & & 3.31 \\
\hline JUSCANZ & & - & - & & - & & - & $\begin{array}{l}4 . \\
(2 .\end{array}$ & $\begin{array}{l}46 \\
87)\end{array}$ & & .24 \\
\hline EU & & - & - & & $\begin{array}{c}40.68^{* * *} \\
(4.58)\end{array}$ & & - & $\begin{array}{l}1 . \\
(1 .\end{array}$ & & & $\begin{array}{l}84 \\
6.59)\end{array}$ \\
\hline NATO & & - & - & & $\begin{array}{c}-22.24^{* * * *} \\
(3.26)\end{array}$ & & - & $\begin{array}{l}-0 \\
(1 .\end{array}$ & & & $\begin{array}{l}0.66 \\
4.80)\end{array}$ \\
\hline G77 and NAM & & - & $\begin{array}{l}1.7 \\
(1.8\end{array}$ & & - & & $\begin{array}{l}3^{* * * *} \\
.99)\end{array}$ & - & & & $\begin{array}{l}6.43 \\
.51)\end{array}$ \\
\hline G77 only, not in NAM & & - & $\begin{aligned}-7.7 \\
(4.4\end{aligned}$ & & - & & $\begin{array}{l}64^{* *} \\
.85)\end{array}$ & - & - & & 8.10 \\
\hline NAM only, not in G77 & & - & - & & - & & - & - & - & & $\begin{array}{l}7.54 \\
4.69)\end{array}$ \\
\hline Peacekeeping troops $(\log )$ & & $\begin{array}{l}20^{*} \\
11)\end{array}$ & $\begin{array}{r}0.41 \\
(0.1\end{array}$ & & $\begin{array}{l}0.08 \\
(0.34)\end{array}$ & & $\begin{array}{l}.23 \\
.16)\end{array}$ & $\begin{array}{l}0 . \\
(0 .\end{array}$ & & & $\begin{array}{l}.42 \\
.03)\end{array}$ \\
\hline Democracy & & $\begin{array}{l}82 \\
69)\end{array}$ & $\begin{array}{l}1.82 \\
(1.11)\end{array}$ & $\begin{array}{l}-1.52 \\
(1.02)\end{array}$ & $\begin{array}{c}-20.02^{* * *} 16.79^{* * * *} \\
(2.27) \\
(3.10)\end{array}$ & $\begin{array}{c}-1.53^{* *} \\
(0.77)\end{array}$ & $\begin{array}{l}19.42^{* * *} \\
(2.01)\end{array}$ & $\begin{array}{l}8.7 \\
(4 .\end{array}$ & & & $\begin{array}{l}.88^{* *} \\
.47)\end{array}$ \\
\hline Former British colony & & $\begin{array}{l}06 \\
59)\end{array}$ & $\begin{array}{r}4.19 \\
(1.1\end{array}$ & & - & & $\begin{array}{l}75^{* *} \\
.68)\end{array}$ & $\begin{array}{l}7.7 \\
(3 .\end{array}$ & & & .05 \\
\hline Former French colony & & $\begin{array}{l}65 \\
46)\end{array}$ & - & & - & & - & - & - & & $\begin{array}{l}6.36 \\
4.99)\end{array}$ \\
\hline Conflict & $\begin{array}{l}-0.62 \\
(0.89)\end{array}$ & $\begin{array}{c}-18.49^{* * *} \\
(1.91)\end{array}$ & $\begin{array}{l}-1.8 \\
(1.3\end{array}$ & & - & $\begin{array}{l}2.33^{* *} \\
(1.13)\end{array}$ & $\begin{array}{c}-17.85^{* * *} \\
(1.88)\end{array}$ & - & - & $\begin{array}{l}21.53 \\
(37.99)\end{array}$ & $\begin{array}{c}-182.25 \\
(143.71)\end{array}$ \\
\hline Muslim (\%) & & $\begin{array}{l}14 \\
96)\end{array}$ & $\begin{array}{r}2.4 \\
(1.0\end{array}$ & & $\begin{array}{l}-4.49 \\
(4.66)\end{array}$ & $\begin{array}{c}0.16 \\
(14.19)\end{array}$ & $\begin{array}{c}-286.20^{* * * *} \\
(32.85)\end{array}$ & $\begin{array}{r}-297 \\
(131\end{array}$ & $\begin{array}{l}.99^{* *} \\
.44)\end{array}$ & $\begin{array}{l}-40.74 \\
(64.10)\end{array}$ & $\begin{array}{c}-147.55^{* *} \\
(59.09)\end{array}$ \\
\hline Catholic (\%) & & $\begin{array}{l}02 \\
02)\end{array}$ & $\begin{array}{r}-90.6 \\
(35 .\end{array}$ & $66^{* *}$ & $\begin{array}{l}2.29 \\
(2.36)\end{array}$ & & .90 & $\begin{array}{l}-3 . \\
(3 .\end{array}$ & $\begin{array}{l}84 \\
52)\end{array}$ & & $\begin{array}{l}.51 \\
5.65)\end{array}$ \\
\hline Shared regional ideology & & $\begin{array}{l}59 \\
14)\end{array}$ & $\begin{array}{l}1.6 \\
(3.2\end{array}$ & & $\begin{array}{l}3.98 \\
(2.79)\end{array}$ & & $\begin{array}{l}.70^{*} \\
.89)\end{array}$ & $\begin{array}{l}10.98 \\
(14.62)\end{array}$ & $\begin{array}{l}1.78 \\
(4.02)\end{array}$ & & .01 \\
\hline Control of corruption & & $\begin{array}{l}75^{*} \\
40)\end{array}$ & $\begin{array}{l}0.3 \\
(0.8\end{array}$ & & $\begin{array}{l}1.54 \\
(2.13)\end{array}$ & & $\begin{array}{l}.01^{* * *} \\
.50)\end{array}$ & $\begin{array}{l}0.8 \\
(1 .\end{array}$ & $\begin{array}{l}85 \\
76)\end{array}$ & $\begin{array}{l}-29.41 \\
(18.48)\end{array}$ & $\begin{array}{l}15.69 \\
(19.82)\end{array}$ \\
\hline Arab seat & & $\begin{array}{l}1^{* * * *} \\
42)\end{array}$ & $\begin{array}{r}27.7 \\
(3.3\end{array}$ & & - & & - & - & & & .86 \\
\hline
\end{tabular}

Numbers in parentheses are robust standard errors clustered on region $\times$ year. ${ }^{*}$ significant at $10 \%,{ }^{* *}$ significant at $5 \%,{ }^{* * * *}$ significant at $1 \%$. 
Table 3b: Model 2

\begin{tabular}{|c|c|c|c|c|c|c|}
\hline \multirow[t]{2}{*}{ Variables } & Africa & Asia & $\mathrm{EE}$ & GRULAC & WEOG & UNGA \\
\hline & $\leq 1989 \quad>1989$ & $\leq 1989 \quad>1989$ & $\leq 1989 \quad>1989$ & & $\leq 1989 \quad>1989$ & \\
\hline Turn-taking norm & $\begin{array}{c}3.84^{* * *} \\
(0.72)\end{array}$ & $\begin{array}{c}6.42^{* * *} \\
(1.81)\end{array}$ & $\begin{array}{c}1.05^{* * *} \\
(0.40)\end{array}$ & $\begin{array}{l}1.46^{* *} \\
(0.59)\end{array}$ & $\begin{array}{l}5.07^{* * * *} \\
(1.15)\end{array}$ & - \\
\hline GNI per capita (log) & $\begin{array}{l}0.52^{* *} \\
(0.22)\end{array}$ & $\begin{array}{l}1.21^{* * *} \\
(0.34)\end{array}$ & - & $\begin{array}{c}1.43^{* * * *} \\
(0.41)\end{array}$ & - & - \\
\hline Population (log) & $\begin{array}{c}0.46^{* * *} \\
(0.14)\end{array}$ & $\begin{array}{c}3.58^{* * *} \\
(0.94)\end{array}$ & - & $\begin{array}{c}0.92^{* * *} \\
(0.28)\end{array}$ & $\begin{array}{l}3.61^{* * *} \\
(0.77)\end{array}$ & - \\
\hline Territory (log) & - & $\begin{array}{l}0.52^{*} \\
(0.28)\end{array}$ & $\begin{array}{c}2.12^{* * * *} \\
(0.80)\end{array}$ & $\begin{array}{l}0.76^{* * *} \\
(0.24)\end{array}$ & - & - \\
\hline Russia voting in the UNGA & $\begin{array}{l}6.59^{* *} \\
(3.34)\end{array}$ & - & - & $\begin{array}{l}8.39^{* *} \\
(3.48)\end{array}$ & - & $\begin{array}{c}231.63^{* *} \\
(95.44)\end{array}$ \\
\hline Pariah state & $\begin{array}{cc}-16.40^{* * * *} & -\end{array}$ & $\begin{array}{c}-18.44^{* * * *} \\
(1.84)\end{array}$ & - & $\begin{array}{c}-13.67^{* * *} \\
(2.68)\end{array}$ & - & - \\
\hline New World Bank projects & $\begin{array}{c}0.24^{* *} \\
(0.10)\end{array}$ & $\begin{array}{l}0.29^{* * *} \\
(0.10)\end{array}$ & - & - & $\begin{array}{l}0.95 \\
(0.60)\end{array}$ & $\begin{array}{l}-6.35^{* *} \\
(2.56)\end{array}$ \\
\hline US economic aid (log) & - & - & - & - & $\begin{array}{c}-0.14^{* *} \\
(0.06)\end{array} \quad-$ & - \\
\hline US military aid (log) & - & - & $\begin{array}{c}0.32^{* *} \\
(0.14)\end{array}$ & - & $\begin{array}{c}-0.24^{* * *} \\
(0.09)\end{array}$ & $\begin{array}{l}4.75^{* * *} \\
(1.28)\end{array}$ \\
\hline Debt service (\% GNI) & $\begin{array}{l}0.86^{* * *} \\
(0.30)\end{array}$ & - & - & $\begin{array}{l}0.89^{*} \\
(0.51)\end{array}$ & - & - \\
\hline JUSCANZ & - & - & - & - & - & $\begin{array}{l}31.06 \\
(19.74)\end{array}$ \\
\hline EU & - & - & $\begin{array}{c}39.89^{* * *} \\
(1.99)\end{array}$ & - & $\begin{array}{l}1.25 \\
(0.87)\end{array}$ & - \\
\hline NATO & - & - & $-\quad \begin{array}{c}-22.70^{* * *} \\
(1.38)\end{array}$ & - & - & - \\
\hline G77 and NAM & - & - & - & $\begin{array}{c}3.58^{* * *} \\
(1.15)\end{array}$ & - & - \\
\hline G77 only, not in NAM & - & $\begin{array}{c}-12.99^{* * *} \\
(3.01)\end{array}$ & - & $\begin{array}{c}2.34^{* *} \\
(1.03)\end{array}$ & - & - \\
\hline NAM only, not in G77 & - & - & - & - & - & - \\
\hline Peacekeeping troops (log) & $\begin{array}{l}0.19^{* *} \\
(0.09)\end{array}$ & $\begin{array}{c}0.30^{* * *} \\
(0.09)\end{array}$ & - & - & - & - \\
\hline Democracy & - & $\begin{array}{c}-1.87^{* * *} \\
(0.75)\end{array}$ & $\begin{array}{c}-19.67^{* * *} 16.29^{* * *} \\
(1.40)\end{array}$ & $\begin{array}{cc}-1.23^{*} & 19.70^{* * * *} \\
(0.69) & (1.25)\end{array}$ & $\begin{array}{c}10.73^{* * *} \\
(2.20)\end{array}$ & - \\
\hline Former British colony & - & $\begin{array}{l}3.66^{* * *} \\
(1.00)\end{array}$ & - & $\begin{array}{l}1.61^{* *} \\
(0.70)\end{array}$ & $\begin{array}{c}6.33^{* * * *} \\
(2.07)\end{array}$ & - \\
\hline Conflict & $\begin{array}{c}-18.80^{* * *} \\
(0.98)\end{array}$ & $\begin{array}{r}-1.45 \\
(1.05)\end{array}$ & - & $\begin{array}{cc}2.52^{* *} & -20.32^{* * * *} \\
(1.02) & (1.61)\end{array}$ & - & - \\
\hline Muslim (\%) & - & $\begin{array}{l}1.81^{*} \\
(1.06)\end{array}$ & - & $-\quad \begin{array}{c}-262.06^{* * *} \\
(30.50)\end{array}$ & $\begin{array}{c}-209.38^{* * * *} \\
(81.46)\end{array}$ & - \\
\hline Catholic (\%) & - & $\begin{array}{c}-76.16^{* *} \\
(30.34)\end{array}$ & - & - & $\begin{array}{c}-4.36^{* * *} \\
(1.65)\end{array}$ & - \\
\hline Shared regional ideology & - & - & $\begin{array}{l}3.55^{* *} \\
(1.75)\end{array}$ & $\begin{array}{l}3.97^{* *} \\
(1.72)\end{array}$ & - & - \\
\hline Control of corruption & $\begin{array}{c}-0.58^{*} \\
(0.30)\end{array}$ & - & $\begin{array}{l}1.06 \\
(0.81)\end{array}$ & $\begin{array}{c}-0.86^{* *} \\
(0.39)\end{array}$ & - & $\begin{array}{cc}21.99^{* *} \\
(10.60)\end{array}$ \\
\hline Arab seat & $\begin{array}{c}1.50^{* * * *} \\
(0.30)\end{array}$ & $\begin{array}{l}24.13^{* * *} \\
(2.16)\end{array}$ & - & - & - & - \\
\hline
\end{tabular}

Numbers in parentheses are robust standard errors clustered on region $\times$ year. ${ }^{*}$ significant at $10 \%,{ }^{* *}$ significant at $5 \%,{ }^{* * *}$ significant at $1 \%$. 